\title{
Magnetic susceptibility evolution and sedimentary environments on carbonate platform sediments and atolls, comparison of the Frasnian from Belgium and Alberta, Canada
}

\author{
Anne-Christine da Silva ${ }^{\mathrm{a}, *}$, Ken Potma ${ }^{\mathrm{b}}$, John A.W. Weissenberger ${ }^{\mathrm{c}}$, Michael T. Whalen ${ }^{\mathrm{d}}$, Marc Humblet ${ }^{\mathrm{e}}$, \\ Cédric Mabille ${ }^{\mathrm{a}}$, Frédéric Boulvain ${ }^{\mathrm{a}}$ \\ a Pétrologie Sédimentaire, B20, Boulevard du Rectorat, 15, Université de Liège, 4000 Liège, Belgium \\ ${ }^{\mathrm{b}}$ Imperial Oil Limited, PO Box 2480 Station M Calgary, AB, Canada T2P 3M9 \\ c Citizenship and Immigration Canada, 365 Laurier Avenue West Ottawa, Canada ON K1A 1L1 \\ d Department of Geology and Geophysics, University of Alaska, Fairbanks, Alaska 99775, USA \\ e Institute of Geology and Paleontology, Graduate School of Science, Tohoku University, Aobayama, Sendai 980-8578, Japan
}

\section{A R T I C L E I N F O}

Keywords:

Frasnian

Magnetic susceptibility

Correlations

Platforms and atolls

\begin{abstract}
A B S T R A C T
Magnetic susceptibility (MS) measurements on carbonate rocks are considered as a proxy for impurities delivered to the carbonate environments. In the absence of strong climatic or tectonic variations, bulk MS values have been linked to sea level variations, because sea-level fall increases clastic supply and therefore increases in magnetic mineral deposition. In this paper we explore the relationship between the average magnitude of bulk MS, with shallowing-up sequences and facies evolution in different Devonian carbonate complexes. Similarities and differences between these parameters have been scrutinized in carbonate attached platform and detached platforms (mounds and/or atolls) from Belgium and Canada.

In the carbonate attached platforms from Belgium and Canada, the MS patterns are directly related to depositional environment. Mean MS values increase from the most distal towards the most proximal facies and towards the top of the majority of fourth-order shallowing-up sequences. These trends are in agreement with theoretical background (MS increases with regression).

In the Belgian detached platform, the average MS pattern generally shows an opposite behaviour to that observed in the attached carbonate platforms. Average MS decreases towards the most proximal facies and towards the top of a majority of the fourth-order shallowing-up sequences. This behaviour can be explained by the influence of sedimentary rate and water agitation during deposition. A high sedimentary rate will dilute the magnetic minerals in the atoll facies and the high water agitation during deposition may be expected to have prevented the deposition of the magnetic grains. So, the combination of these two effects will result in the observed low values in the atoll crown and lagoonal facies. In the Canadian detached platform, MS is mainly negative. This means that the limestones are very pure. The technique does not appear to be appropriate in these rocks.

The variations of average MS behaviour by platform type can imply difficulties in correlating carbonates from different settings. A comparison of time equivalent mound and platform deposits shows that after an important regressive surface, the MS values are increasing for the platform deposits and decreasing for the mound. So MS evolution can be in complete opposition (caused by highly different sedimentary rates) in different depositional settings. The MS signal preserved in carbonate rocks is probably mainly related to 1) varying clastic supplies; 2) varying carbonate accumulation rates (dilution of the magnetic minerals by high carbonate production) and 3) potentially diagenesis.
\end{abstract}

(c) 2008 Elsevier B.V. All rights reserved.

\section{Introduction}

Since the work of Crick et al. (1997, 2000, 2001, 2002) and Ellwood et al. (1999, 2000, 2001, 2006, 2007) on the use of magnetic susceptibility (MS) in correlating Palaeozoic sediments, this technique

\footnotetext{
* Corresponding author. Tel.: +32 4 3662258; fax: +32 43662029 .

E-mail address: ac.dasilva@ulg.ac.be (A.-C. da Silva).
}

has become widely used (Racki et al., 2002; Hladil et al., 2003a, 2004, 2005; Whalen and Day, 2005; da Silva and Boulvain, 2002, 2003, 2006; Mabille and Boulvain, 2007). Crick et al. (1997) defined the correlations obtained with MS as intercontinental, facies independent and of a better precision than biozones. Ellwood et al. (2000) contended that MS is directly related to lithogenic inputs. Eustatic sea-level changes result in base-level fluctuations that cause variations in erosion and detrital influx to the world's oceans (Davies et al., 1977; Worsley and Davies, 1979). Eustatic changes in sea-level 
therefore affect MS values. During eustatic sea-level rise detrital supply decreases and during high sea-level, average MS values are low. During eustatic sea-level fall detrital supply increases and during low sea-level, average MS values are high (Crick et al., 1997; Ellwood et al., 2000). In addition to "classical" aquatic delivery, different authors considered that important amounts of magnetic minerals in carbonate rocks are related to supply from eolian suspension and atmospheric dust (Hladil, 2002; Hladil et al., 2005).

This paper compares MS behaviour on carbonate attached platforms and carbonate detached platforms. These terms were defined by Handford and Loucks (1993). Carbonate platform may be isolated (detached) from or they may be linked (attached) to a large siliciclastic sourcing landmass, such as a continent or large island. Attached platforms are commonly long, linear features that face open seas, usually along passive continental margins. This term is general and includes "attached rimmed shelf" and "attached flat-topped shelf (or unrimmed)" (Handford and Loucks, 1993, p. 11, 12).

Correlating attached carbonate platform sediments with time equivalent carbonate detached platforms can be problematic. The aim of this study is to identify the impact of depositional environment on the MS signal on these different carbonate platform types. We propose that MS measurements on carbonate deposits can be strongly influenced by the sedimentary rate and by the water agitation during deposition. These influences can result in correlative problems between different depositional settings.

\section{Geological setting}

The studied material is from two major depositional settings. The first depositional environment is the attached carbonate platform, which outcrops in Belgium (Barse, Tailfer, Aywaille and Villers) and in Alberta (Yamnuska). The second one is the carbonate detached platform (atolls) which is studied in outcrops in Belgium (Moulin Bayot, Lion, La Boverie and Lompret sections) and in subsurface cores in Belgium (Nord) and in Alberta (Redwater and Golden Spike atoll reefs).

During the Frasnian, Belgium and Alberta were located in relatively similar paleogeographic position (Fig. 1) (McKerrow and Scotese,
1990; Copper, 2002; Kiessling et al., 2003). This location, close to the paleoequator, led to the development of widespread carbonate platforms, with comparable facies. The Belgian platform developed at $20^{\circ}$ south (Kiessling et al., 2003; Torsvik and Cocks, 2004), in the Paleotethys sea (Heckel and Witzke, 1979). The western Canadian platform developed around $15^{\circ}$ south (Kiessling et al., 2003) along the western margin of Laurentia (Heckel and Witzke, 1979).

The Middle Frasnian (early Late Devonian) was a time of a globally warm (greenhouse) climate (for a recent review, see Streel et al., 2000; Joachimski et al., 2004; Hladil et al., 2005) and of high sea level (Vail et al., 1977; Johnson et al., 1985; and for a recent review, see Hladil, 2002). During the Devonian, the Earth's surface temperature reaches a peak during the Givetian and according to Streel et al. (2000) those hot climates lasted until the Latest Frasnian. During the Frasnian, this hot period was interrupted by two short-term cooling events in the Late rhenana zone and at the base of the Frasnian-Famennian transition (Joachimski et al., 2004) (which is younger than studied interval, see here-under). Hladil et al. (2005) suggested that the Early-Middle Frasnian was a period of uniform climate.

\subsection{Geological setting of the Frasnian in Belgium}

During the Middle part of the Frasnian, an extensive carbonate platform developed in Belgium (Fig. 2) (Boulvain et al., 1999). In the more distal part (SW of Belgium, southern border of the Dinant Synclinorium), the Middle Frasnian succession (Moulin Liénaux and Grand Breux Formations) is characterized by three carbonate mound and atoll levels (Arche, La Boverie and Lion members) separated by argillaceous intervals (Boulvain, 2001) (Fig. 2B). In the intermediate part of the basin (Philippeville Anticline), argillaceous, crinoidal and biostromal facies (Pont-de-la-Folle and Philippeville Formations) are present and in the proximal part of the basin (northern border of the Dinant Synclinorium, Vesdre Synclinorium and southern border of the Namur Synclinorium), stromatoporoid biostromes and lagoonal facies developed (Lustin Formation). These formations studied herein, were deposited during the transitans to early rhenana conodont zone or Montagne Noire conodont zones 4-7 (Klapper, 1988; Gouwy and Bultynck, 2000) (Fig. 2B).

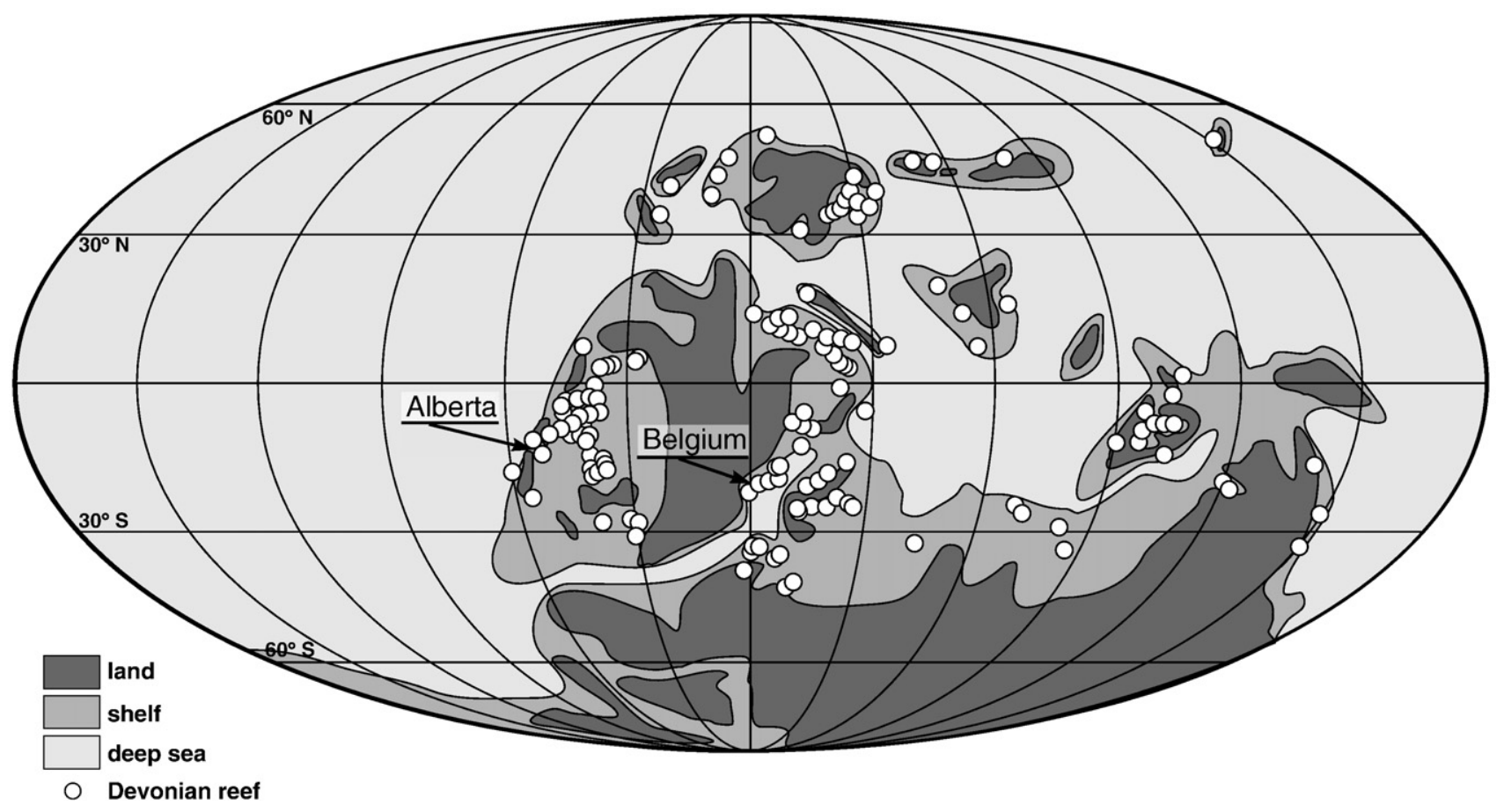

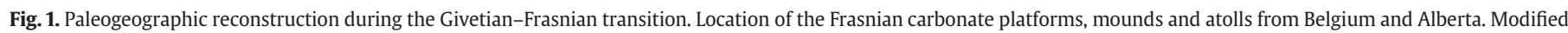
after Kiessling et al. (2003). 

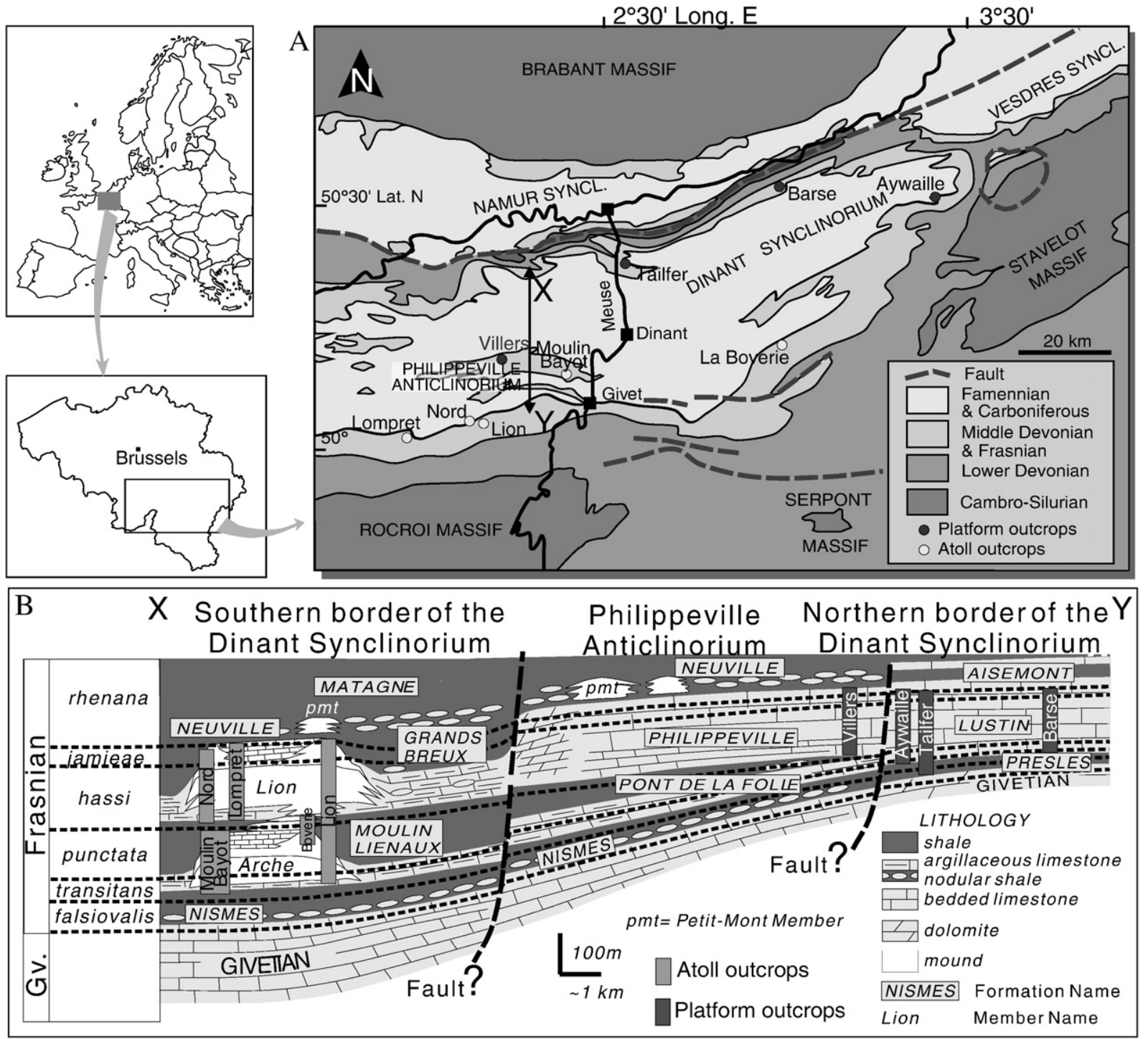

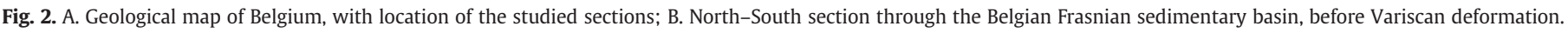
Letters X and Y correspond to the line X-Y on A. Conodont zonations are drawn after Gouwy and Bultynck (2000).

The sections studied in this paper, located at Tailfer, Aywaille and Barse (Lustin Formation) and Villers (Philippeville Formation), represent shallow-water and intermediate carbonate platform settings, whereas the Moulin Bayot, Lion, Nord, La Boverie and Lompret sections are distal atoll deposits (Fig. 2B and Table 1).

\subsection{Geological setting of the Frasnian in Alberta}

During the late Middle and early Late Devonian (GivetianFrasnian) the Alberta basin was a large intra-cratonic sea located on the western margin of the North American craton. Numerous carbonate banks and platforms rimmed this sea. Land masses, transgressed by the end of the Devonian, were present on the west and northwest (the West-Alberta ridge and the Peace River Arch) and to the Northeast (Canadian Shield) (Fig. 3B). A system of attached and detached platforms, with a distinct NE-SW trend developed in the Frasnian (Potma et al., 2001) (Fig. 4).

The stratigraphic nomenclature for the Frasnian is divided in two parts (Fig. 3C). "Surface" terminology is used for outcrops in the Rocky Mountains and is mainly characterized by platform deposits (Cairn Formation and Peechee Member) with an alternation of biostromes and lagoonal deposits (Mallamo and Geldsetzer, 1991). "Subsurface" terminology is used for the oilfield cores from the east of the Rocky Mountains, in central Alberta. The subsurface is characterized by high relief Leduc Formation reefs surrounded by Duvernay and Ireton Formation shales (Meijers Drees and Geldsetzer, 1984) (Fig. 4). Sequence stratigraphic frameworks are proposed by van Buchem et al. (1996), Whalen et al. (2000a), and Potma et al. (2001).

The sections studied herein is the Yamnuska section, located in the Fairholme complex (carbonate attached-platform), in the eastern border of the Canadian Rockies (Fig. 3B). The lower part of the section is in the Cairn Formation and the upper part in the Peechee Member (Table 1). This section is completely dolomitized and falls within the punctata to lower rhenana conodont zones (Montagne Noire Conodont zones 5-12).

The studied cores are from the Golden Spike and the Redwater atoll reefs. They are mainly from the Leduc Formation (punctata to lower rhenana zones or Montagne Noire Conodont zones 5-12) (Fig. 4).

\section{Methods}

This paper compares the MS evolution with environmental parameters. To reach this goal, an understanding of the sedimentological facies and depositional environments is necessary. For each 
Table 1

Sections studied in this paper with their name; $m$ : studied thickness; $n$ : number of samples and magnetic susceptibility measurements; corresponding formation names and FM: corresponding facies model described in Section 4 and in Fig. 5

\begin{tabular}{lccll}
\hline Name & $m$ & $n$ & Formation name & FM \\
\hline Belgian outcrops (attached platform) & & & \\
Villers & $105 \mathrm{~m}$ & 242 & Philippeville & PF \\
Tailfer & $105 \mathrm{~m}$ & 268 & Lustin & PF \\
Aywaille & $120 \mathrm{~m}$ & 260 & Lustin & PF \\
Barse & $46 \mathrm{~m}$ & 120 & Lustin & PF \\
Belgian outcrops and cores (atolls and mounds) & & \\
Lion & $445 \mathrm{~m}$ & 133 & Moulin Lienaux-Grands & BMA \\
Lompret & $48 \mathrm{~m}$ & 77 & Breux & BMA \\
Moulin Bayot & $118 \mathrm{~m}$ & 187 & Grands Breux & BMA \\
Nord & $375 \mathrm{~m}$ & 375 & Moulin Lienaux & BMA \\
La Boverie & $440 \mathrm{~m}$ & 195 & Grands Breux & BMA \\
Canadian outcrop (attached platform) & & & \\
\multicolumn{7}{l}{ Yamnuska } & $330 \mathrm{~m}$ & 170 & Cairn and Peechee & PF \\
Canadian cores (atolls) & & & & \\
Golden Spike 1 & $414 \mathrm{~m}$ & 590 & Waterways-Leduc & CA \\
11-23-51-27W4 & $1357 \mathrm{ft}$ & & & \\
Golden Spike 2 & $202 \mathrm{~m}$ & 176 & Leduc & CA \\
15-23-51-27W4 & $662 \mathrm{ft}$ & & & \\
Redwater Reef 1 & $303 \mathrm{~m}$ & 260 & Waterways-Leduc & CA \\
05-36-56-21W4 & $993 \mathrm{ft}$ & & & \\
Redwater Reef 2 & $303 \mathrm{~m}$ & 235 & Waterways-Leduc & CA \\
01-22-57-22W4 & $995 \mathrm{ft}$ & & & \\
\hline
\end{tabular}

$\mathrm{PF}$ is Belgian and Canadian platform model; BMA is Belgian mound and atoll model and CA is Canadian atoll model.

sample, an identification of fossils, textures and sedimentary structures leads to a facies classification.

MS measurements were made on the same samples used for thinsection manufacture. The sampling rate applied was different depending on the outcrop or whether the sample was from core (Table 1). Material was limited and the sampling rate lower due to government restriction on core samples and by difficult access to some of the outcrops. Sampling rate in the attached platform of Belgium is the highest (more than 2 samples $/ \mathrm{m}$ ). For the atolls in Canada and Belgium, the sampling rate is around $1 \mathrm{sample} / \mathrm{m}$. In the attached platform outcrop in Canada, we obtained 170 samples for $330 \mathrm{~m}$ of section but significant portions of the section were covered by scree, and the sampling rate is one sample for each $1.5 \mathrm{~m}$. For the atolls of Belgium, the sampling rate is the highest for Lompret, Nord and Moulin Bayot (more than 1 sample per metre) but is very low for Lion and La Boverie ( 1 sample/2 or $3 \mathrm{~m}$ ). No selection was made when choosing the samples for MS measurements, except that fossil-rich or large fossil bearing rocks were rejected to maximize the fine grain-size content of the sample.

Magnetic susceptibility is a measure of the response to an applied magnetic field. MS of a rock depends on its mineralogical composition, mineral grain size, shape of the mineral and orientation of the mineral grains. Natural materials have three major magnetic behaviours: diamagnetic minerals have extremely weak negative values of MS (e.g. calcite and quartz), paramagnetic minerals have weak positive values (e.g. smectite, illite, biotite, dolomite and pyrite) and ferromagnetic minerals have high and positive values (e.g. magnetite, pyrrhotite, hematite, goethite) (Walden et al., 1999).

Crick et al. (1997) showed that the MS signal of a rock is mainly a result of the abundance of paramagnetic and ferromagnetic minerals which have a higher response to an applied magnetic field. Ellwood et al. (2000), suggested that within sedimentary rocks, paramagnetic and ferromagnetic minerals concentration depends on the lithogenic fraction (terrigenous contributions), which is markedly related to eustatism (provided there is no strong climatic or tectonic influence). During low stands of sea level, larger surface areas are subject to weathering, erosion (Hladil, 2002) and the detrital influx to the world's oceans are higher (Davies et al., 1977; Worsley and Davies, 1979). Thus, theoretically (Crick et al., 1997) the highest MS magnitudes represent maximum low stand in sea level and MS signal increases during a sea level fall. Lowest MS magnitude represent maximum high stand in sea level and MS signal decreases during a sea level rise. MS has therefore been used as a proxy for sea level variations (Devleeschouwer, 1999; da Silva and Boulvain, 2002, 2006; Racki et al., 2002; Hladil et al., 2003a,b). Atmospheric dust and eolian supplies were also identified as important mineral carriers (Hladil, 2002; Hladil et al. 2005).

Magnetic susceptibility measurements were performed on the KLY-2 Kappabridge of the University of Lille and on the KLY-3S Kappabridge of

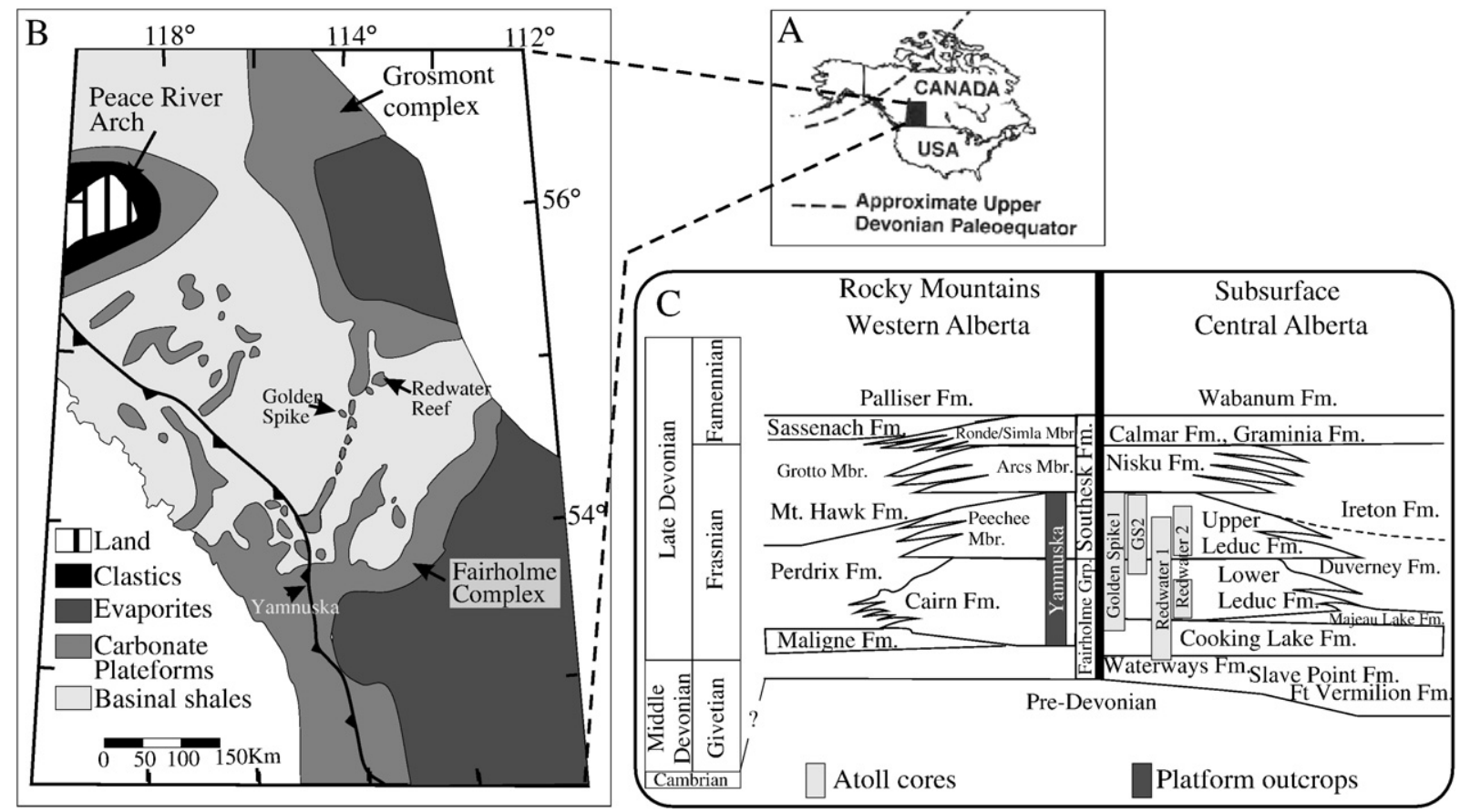

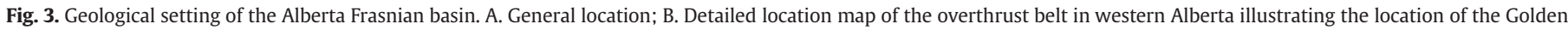

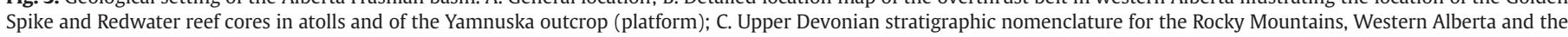
Central Alberta subsurface. GS2 is the abbreviation for the core Golden Spike 2. Modified after Whalen et al. (2000a). 


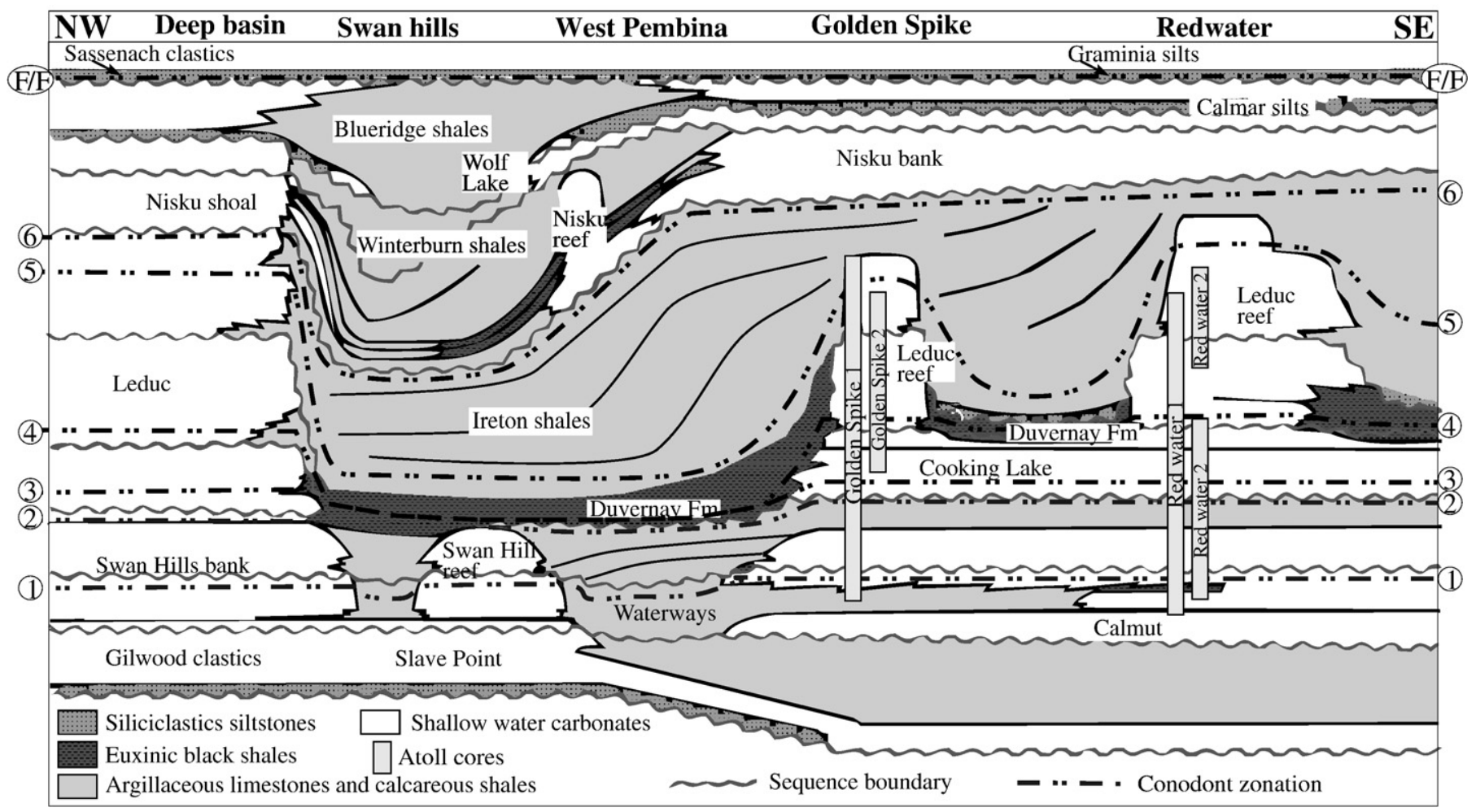

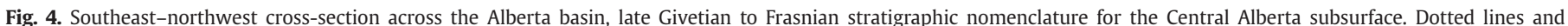

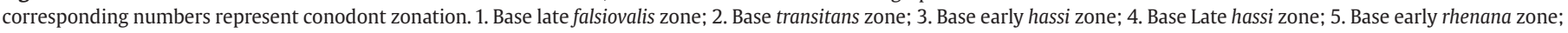
6. Base late rhenana zone; F/F: Frasnian-Famennian boundary. Modified after Potma et al. (2001) and Wendte (1992).

the University of Liège. We used mass-normalized magnetic susceptibility (which is volume magnetic susceptibility multiplied by a reference volume of $1 \mathrm{~m}^{3}$ and divided by the sample mass) expressed in $\mathrm{m}^{3} / \mathrm{kg}$. Measurements are made on each sawn sample weighed with a precision of $0.01 \mathrm{~g}$. The used data presented represent an average of the three measurements.

\section{Sedimentology}

The detailed sedimentological analysis that underpins assessment of MS in this paper is provided by Boulvain et al. (2004) and da Silva and Boulvain (2002, 2004) for Belgium, and by McGillivray and Mountjoy (1975), Weissenberger (1994) and Whalen et al. (2000a,b) for Alberta. A summary is given here to place the MS data in appropriate sedimentological context.

\subsection{Carbonate attached platform from Belgium and Canada}

\subsubsection{Platform facies model (PF, Fig. 5A)}

Belgian and Canadian platform facies are relatively similar. This similarity allows us to propose a single facies model for both carbonate platforms (platform facies model, PF). Facies are presented on Fig. 5A and are ordered from the more distal (PF1) to the more proximal (PF7) environment.

The deposition model starts in the deepest water zone with dark coloured, crinoidal beds and abundant carbonate mud and argillaceous material (mudstone in the deepest zone (facies PF1) and wackestone (facies PF2)). The biostromal zone is mainly built by stromatoporoids (facies PF3). The back-reef or lagoonal zone is characterized by floatstone with branching stromatoporoids (Amphipora), wackestone to packstone-grainstone with calcareous algae (facies PF4) and peloids (facies PF5) in the subtidal area, mudstone and stromatolites (facies PF6) in the intertidal zone and palaeosoils (facies PF7) in the supratidal zone. The Yamnuska section was situated in a relatively shallow-water position and the distal deposits (PF1 and 2) are not represented.

\subsubsection{Platform facies evolution}

The facies model and facies succession lead us to propose a sedimentological evolution curve (Figs. 6 and 7C for Tailfer section in Belgium and Fig. 8 for Yamnuska sections in Alberta). The facies evolution reveals metre-scale cycles, mainly regressive, probably fourthorder. Furthermore, third-order trends are also observed. In Belgium, the lower part of all the Frasnian platform sections is dominated by distal or biostromal facies and the upper part is dominated by proximal lagoonal deposits. These two units are separated by an important regressive surface (da Silva and Boulvain, 2002) (Figs. 6 and 7). In Alberta, the same kind of evolution is observed. The subjacent Cairn Formation corresponds to distal and proximal facies and the super-jacent Peechee Member represents only proximal facies (Fig. 8).

\subsection{Detached carbonate platform from Belgium}

\subsubsection{Belgian mound and atoll (BMA, Fig. 5D) facies model}

A facies model of the middle Frasnian carbonate mounds was developed in previous publications (Boulvain, 2007; da Silva and Boulvain, 2004).

Facies BMA1 corresponds to microbioclastic argillaceous packstones and shales (with some brachiopods, crinoids, fragments of rugose and tabulate corals, fenestellid bryozoans, ostracods and trilobites) which were deposited in the base of the mound or which drowned the mound. Facies BMA2 and 3 correspond to the carbonate mounds sensu stricto, and developed in the deepest environment. Floatstone with stromatactis, corals and crinoids (BMA2) or stromatoporoids (BMA3) developed in a low energy environment, below the storm wave base, and the photic zone.

Floatstone with corals, peloids and Udotaeaceae (BMA4) and microbial limestone (thrombolites and stromatolites) (BMA5) are 


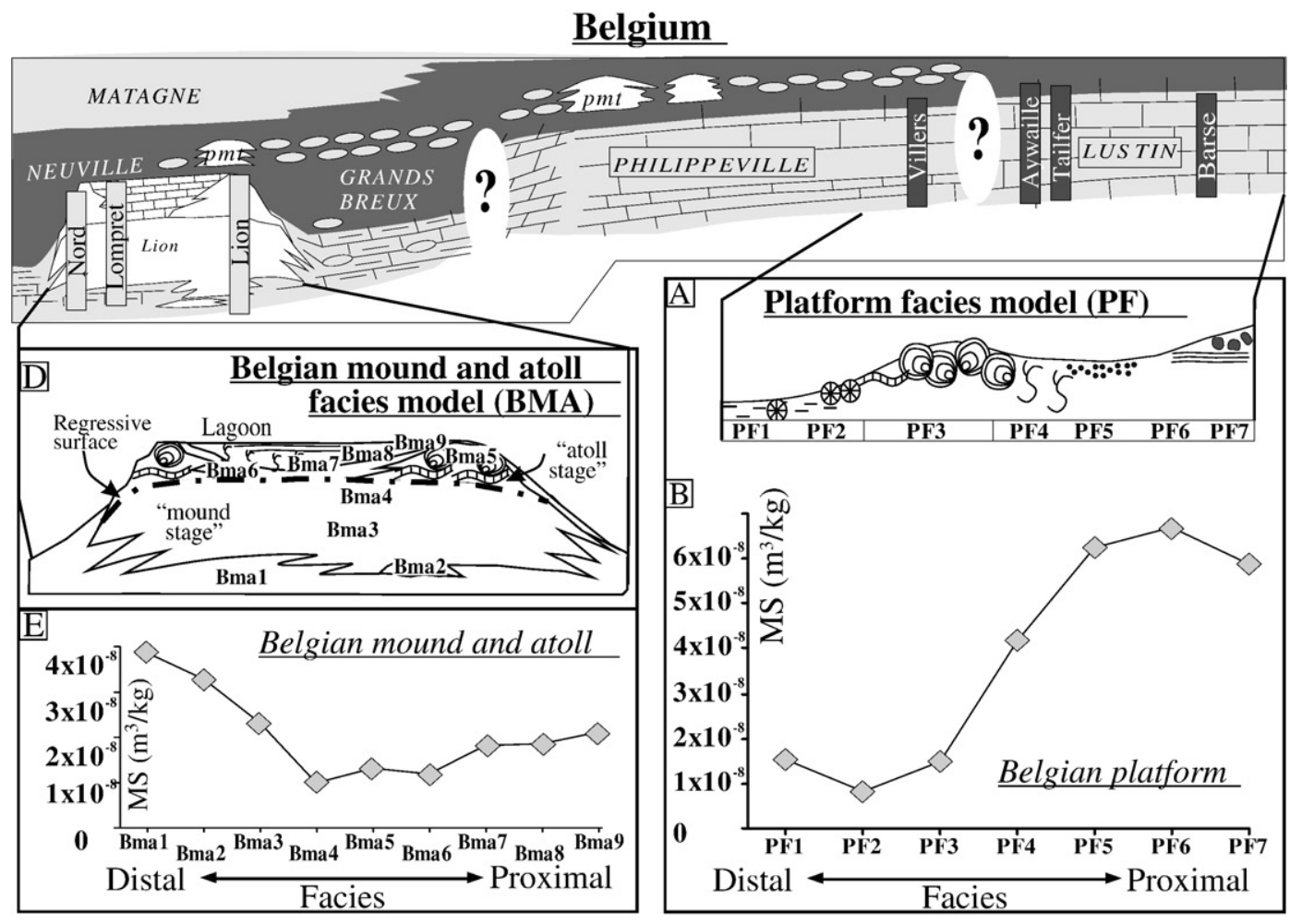

\section{Canada}
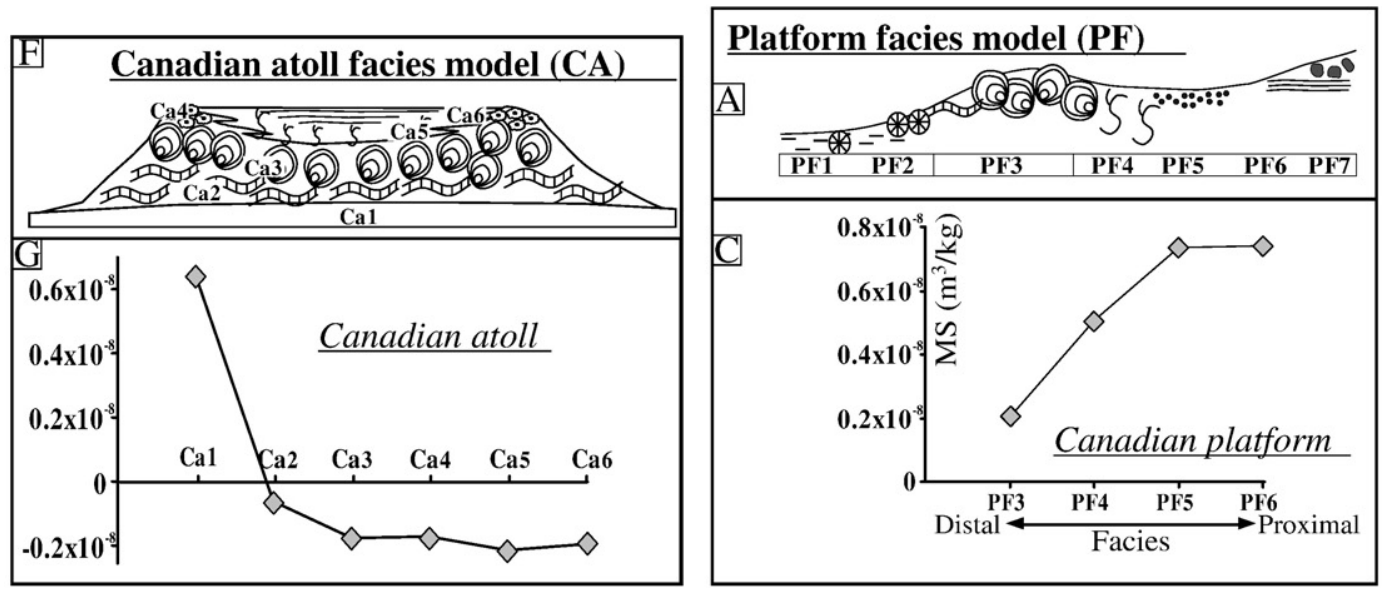

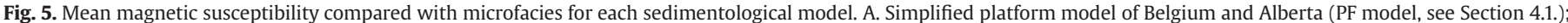

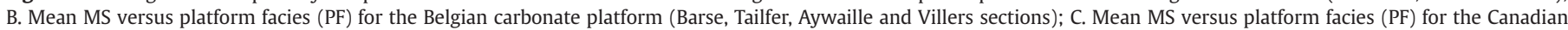

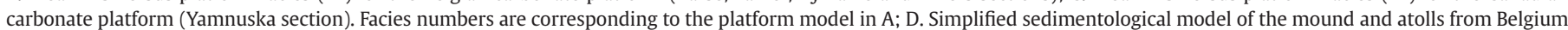

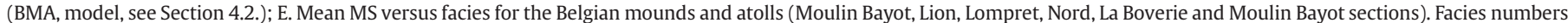

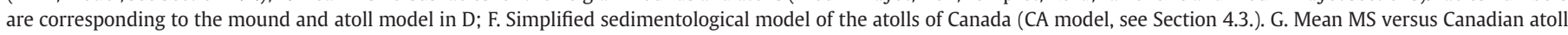
facies (cores Golden Spike 1 and 2 and Redwater 1 and 2). Facies numbers are corresponding to the sedimentological model in F. Legend of A, D and F are in Fig. 7F.

characterized by the first occurrence of green algae and cyanobacteria coating developed in the photic zone, close to the fair-weather wave base.

Facies BMA6, BMA7 and BMA8 correspond to the inner lagoon deposits. Facies BMA6 floatstone and grainstone with dendroid stromatoporoids developed above the fair-weather wave base in a moderate to high energy setting. Facies BMA7 is a fenestral limestone, developed in a very shallow quiet intertidal area and facies BMA8 is a very fine-grained algal limestone deposited in a quiet lagoonal subtidal environment.

\subsubsection{Belgian mound and atoll facies evolution}

A Middle Frasnian Belgian carbonate mound sequence stratigraphic scheme is proposed in Boulvain (2007) (Fig. 6A). Reef initiation occurs during a transgression with the development of the deepest facies (BMA1) and mud or skeletal mound facies (BMA2 and BMA3). Next, a clear progradation corresponding to the HST (reduced accommodation) is recorded by fore-mound sedimentation of reworked material and by algal facies (BMA5) alternating with mud and skeletal mound facies (BMA2-3). During the subsequent lowstand reef growth was restricted to a downslope position, with possible emergence and synsedimentary lithification (Sandberg et al., 1992). During the following transgressive stage algal and microbial mound facies (BMA4 and BMA5) were deposited corresponding to a circular reef margin. The occurrence of relatively restricted facies (BMA6 to BMA8) inside this crown is possibly the result of a balance between sea-level rise and reef growth. During the main regression (regressive 


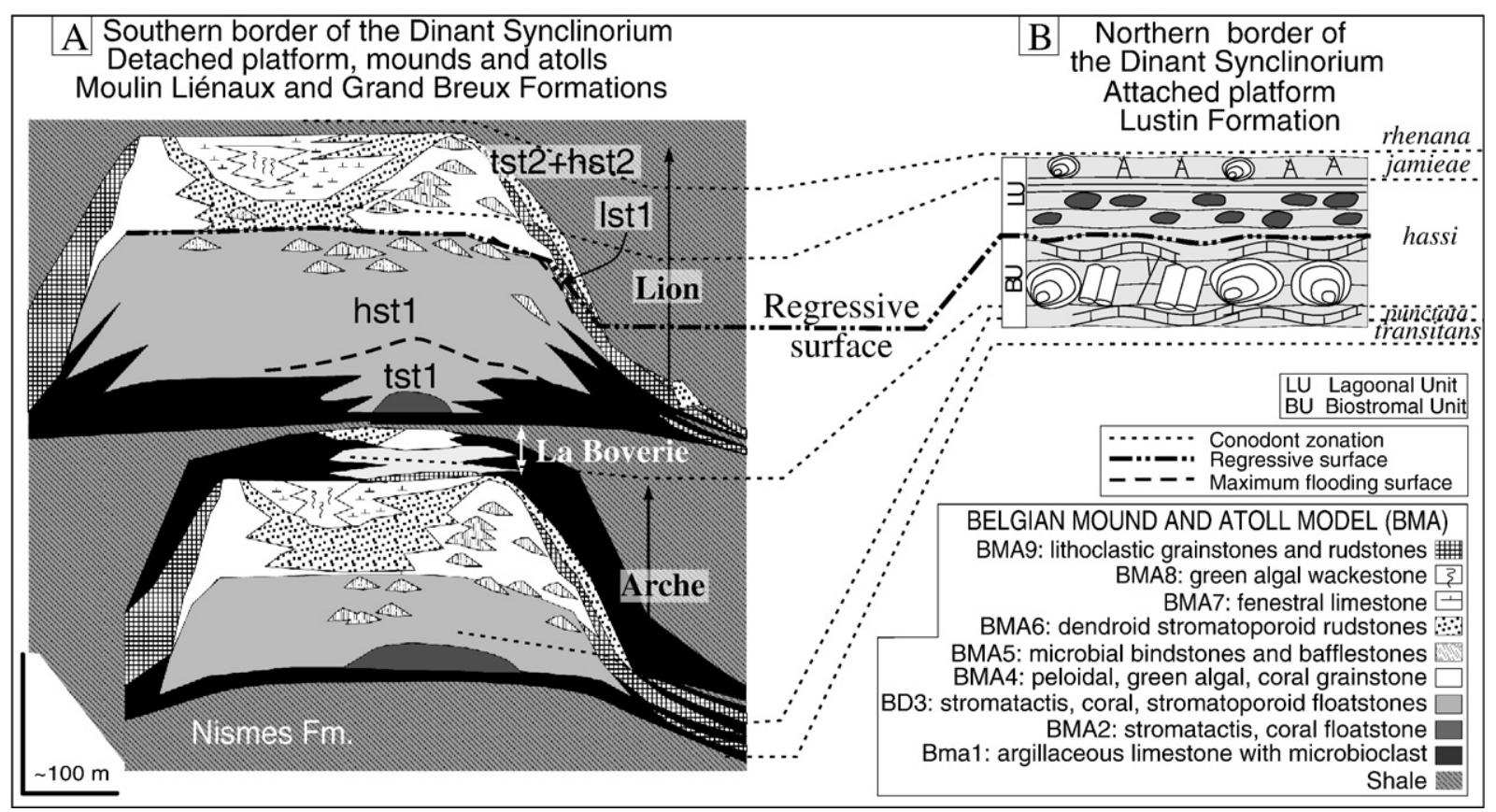

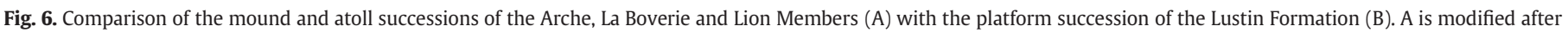
Boulvain (2007). Legend of B is in Fig. 7F.

surface Fig. 6) which causes the emersion of the top of the reef (Sandberg et al., 1992) and the displacement of the facies downslope, some flank deposits are developed corresponding to the dismantling of the top of the mounds (BMA9).

The atoll and mound facies of the Moulin Liénaux (Arche and La Boverie mounds) and Grand Breux Formations (Lion mound) are time equivalent to the Lustin Formation platform. The Arche and La Boverie members correspond to very reduced depositional thickness in the shallowest part of the platform, in the area of the Lustin Formation (see Gouwy and Bultynck, 2000: total thickness of the transitans and punctata corresponding to Arche and La Boverie members is between 150 and $200 \mathrm{~m}$ and thickness of these conodont zones in the Lustin Formation is between 10 and $50 \mathrm{~m}$ ). However, the first stage of the development of the Lion Member (mound facies) corresponds to the upper part of the biostromal unit in the Lustin Formation (Fig. 6). The main regression which causes the emersion of the Lion mound corresponds to the boundary between the biostromal and the lagoonal unit and the development of the atoll crown of the Lion Member corresponds to the lagoonal unit (Fig. 6).

\subsection{Detached carbonate platform from Canada}

\subsubsection{Canadian atoll (CA, Fig. 5F) facies model}

Facies from the more distal zone comprise argillaceous mudstone to packstone with crinoids (CA1) in the basinal or fore-reef or flank zone. The reef margin zone consists of well-developed laminar (CA2) and low domical (CA3) stromatoporoids. The reef flat is characterized by oncolitic grainstone and by coral and stromatoporoid rubble (CA4). In the reef interior, Amphipora floatstones (CA5) were developed in a restricted area (subtidal). Mudstone and algal laminated limestone (CA6) correspond to the semi restricted inter- to supratidal zone.

The main difference between the sedimentological model of the detached platform in Belgium and Canada is that the mud mound stage seen in Belgium was not present in the Canadian platforms.

\subsubsection{Canadian atoll facies evolution}

The Waterway Formation is interpreted as a regressive phase composed of numerous shallowing-upward shale-carbonate alterna- tions (Oldale et al., 1996) (basin to slope depositional environments, grouped in facies CA1). The overlying formation, the Leduc Formation corresponds to the reef development with three major reef stages (Switzer et al., 1994).

\section{Magnetic susceptibility}

5.1. Carbonate attached platform from Belgium and Canada (Platform facies model, PF)

A comparison of magnetic susceptibility results and sedimentological evolution of the carbonate platform of Belgium was proposed by da Silva and Boulvain (2006). The magnetic susceptibility curve is compared to the microfacies evolution curve for the Tailfer section (Fig. 7). The fourth-order cycles identified on the basis of facies stacking patterns can also be identified on the MS evolution curve. Most of the fourth-order regressive cycles culminate with a MS peak on the MS evolution curve (Fig. 7, cycles 1 to 13 and on the enlargement, cycles 3 to 6). Furthermore, the carbonate platform succession of Belgium can be divided into two parts: a lower part, the biostromal unit which is more distal and an upper part, the lagoonal unit which is more proximal separated by a regressive surface (Fig. 6B). The biostromal unit records low mean MS values $\left(2 \times 10^{-8} \mathrm{~m}^{3} / \mathrm{kg}\right)$ and the shallower lagoonal unit is characterized by high mean MS values $\left(6.6 \times 10^{-8} \mathrm{~m}^{3} / \mathrm{kg}\right)$.

The example from the Tailfer section can be extended to the other Belgian sections (Barse, Aywaille and Villers) (da Silva and Boulvain, 2006). Correlations were made on the basis of conodont zonation (Gouwy and Bultynck, 2000), and of MS peaks (da Silva and Boulvain, 2006), which according to Crick et al. (1997) are isochronous. The high-resolution MS data permits more precise correlations between the sections than biostratigraphy (fourth-order correlations).

The microfacies evolution of the Yamnuska section from Alberta also records fourth-order mainly shallow-water regressive cycles (Fig. 8). The MS data on the Yamnuska outcrop display a similar evolution to sections in Belgium. Actually, most of the regressive fourth-order cycles identified on the microfacies evolution curve, a MS increase is obvious (values from 0 at the lower part of the cycle to 


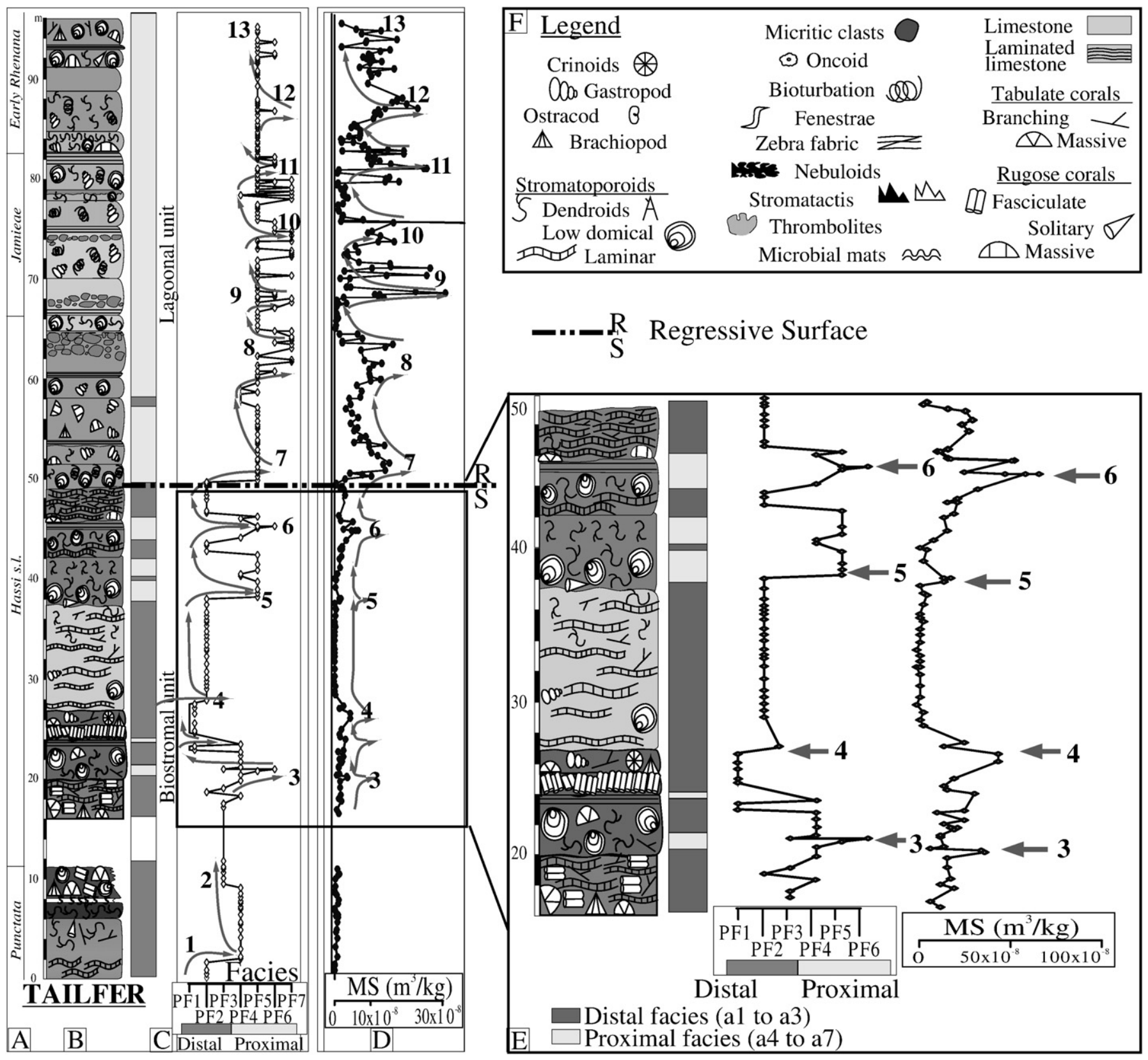

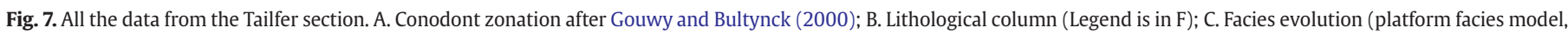

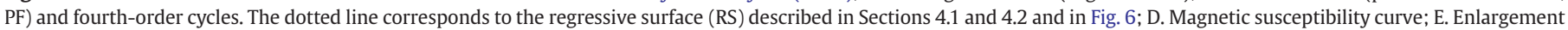
of sequences 3 to 6; F. Legend of Figs. 5-10.

2 or $5 \times 10^{-8} \mathrm{~m}^{3} / \mathrm{kg}$ at the upper shallower part of the cycle). As with the Belgian sections, the Yamnuska section can be divided in a lower deeper part (Cairn Formation) and an upper shallower part (Peechee Member). The MS evolution indicates lower average values in the Cairn Formation $\left(3 \times 10^{-8} \mathrm{~m}^{3} / \mathrm{kg}\right)$ and higher variability and higher average values in Peechee Member $\left(7.8 \times 10^{-8} \mathrm{~m}^{3} / \mathrm{kg}\right)$.

A comparison of mean MS with facies is given in Fig. 5B and $\mathrm{C}$ for the Belgian and Canadian platforms. Both examples show the same pattern; an increase of mean MS values from the deepest to the shallowest facies $\left(1 \times 10^{-8}\right.$ to $7 \times 10^{-8} \mathrm{~m}^{3} / \mathrm{kg}$ in Belgium and $0.1 \times 10^{-8}$ to $0.7 \times 10^{-8} \mathrm{~m}^{3} / \mathrm{kg}$ in Canada).

Magnetic susceptibility evolution is therefore similar in both carbonate platforms, with MS values increasing toward the most proximal facies and towards the top of the fourth-order regressive sequences.
5.2. Detached carbonate platform from Belgium (Belgian mound and atoll, BMA)

Different facies trends are identified in the carbonate mounds from Belgium but the main facies trend is marked by an important regression corresponding to the transition between the deep mud mound facies and the shallowest atoll crown and inner lagoonal deposits (Fig. 6A). Furthermore, different lower order cycles are also observed. This evolution from mud mound to atoll can be observed in the different levels of carbonate mounds (Arche, La Boverie and Lion sections).

A comparison of the cores from the Nord quarry is given in Fig. 9. The main variations in the MS signal correlate with significant facies changes, with the mean highest MS values corresponding to the deepest facies (basinal facies BMA1 and buildup facies BMA2 to 


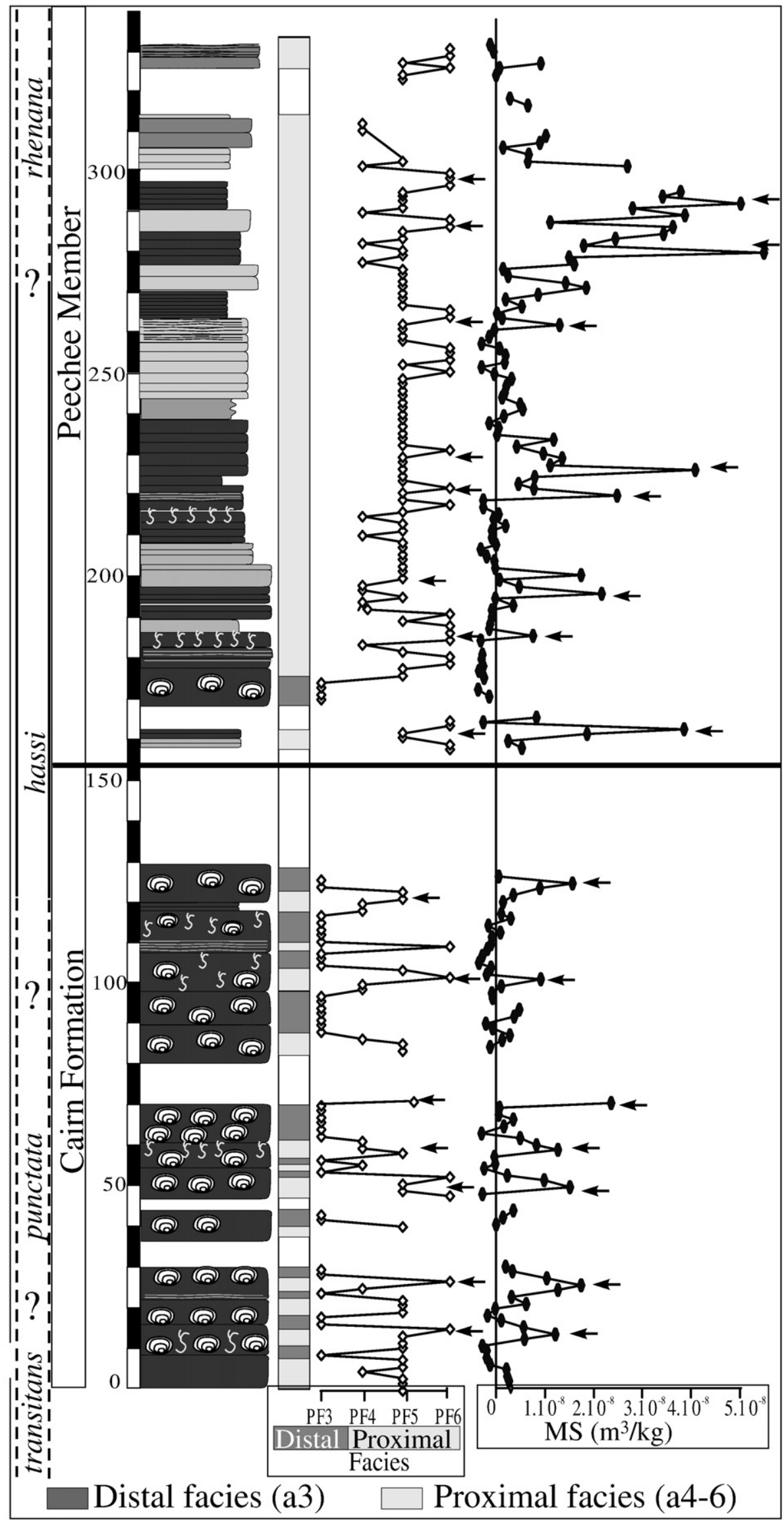

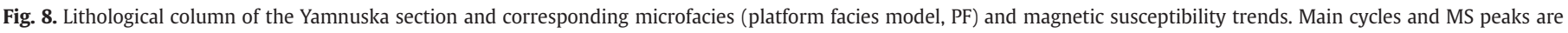
pointed by black arrows. Legend is in Fig. 7F. 

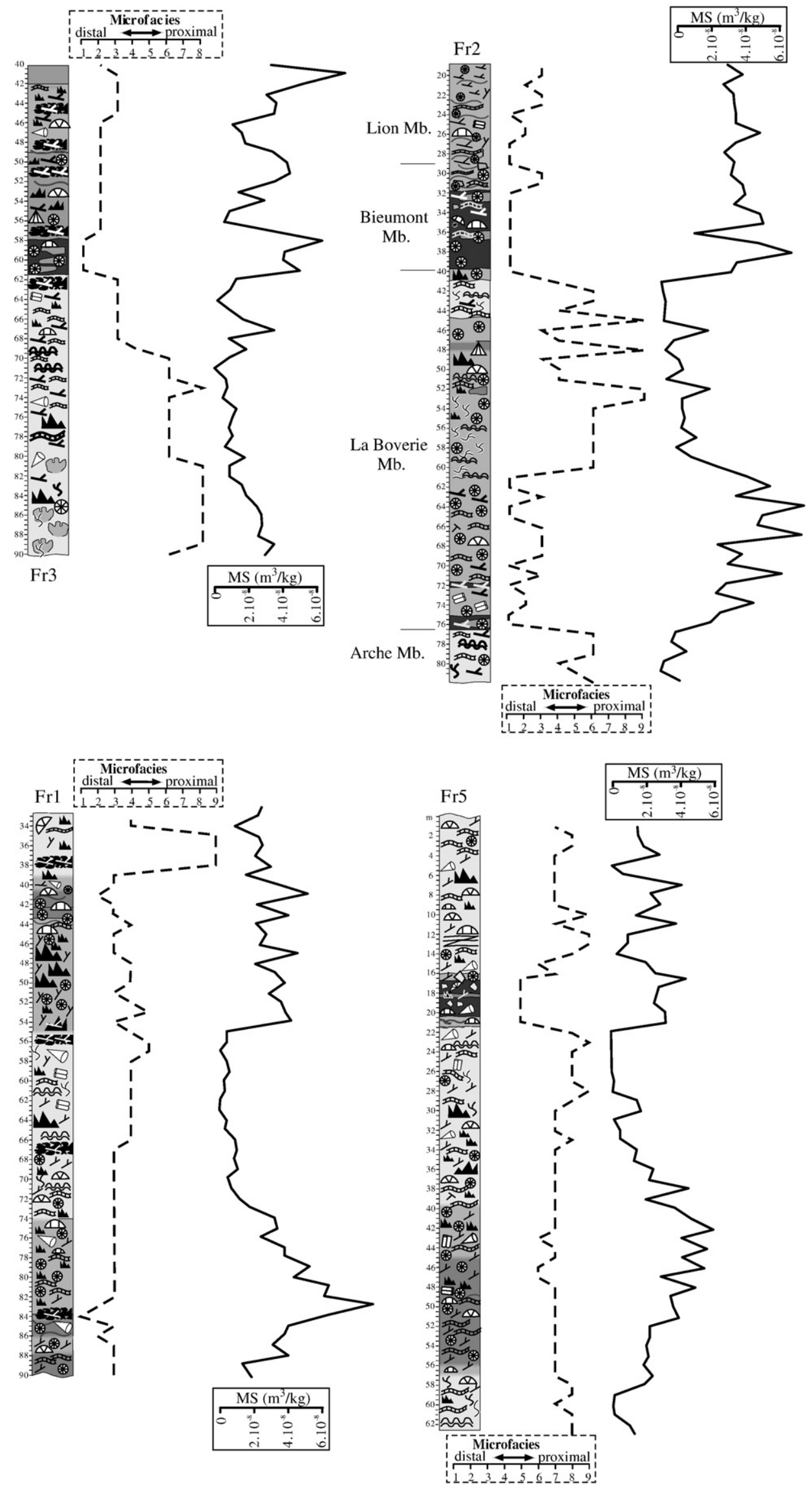

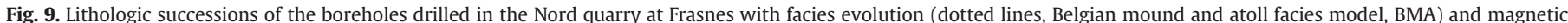
susceptibility curves (MS). This figure shows that for the carbonate mound MS decreases toward the shallowest microfacies. Legend is in Fig. 7F. 
BMA4). A transition between shallow facies and deeper facies corresponds to an increase of average MS.

The comparison of the mean magnetic susceptibility values with the main facies (Fig. 5E) reveals a pattern of MS evolution significantly different from those obtained for the Belgian and Canadian attached platforms (Fig. 5B and C). Basinal facies (BMA1), mud or skeletal mound (red stromatactis wackestone to floatstone, BMA2 and BMA3) and flank deposits have average high values (between $3.5 \times 10^{-8}$ and $1.8 \times 10^{-8} \mathrm{~m}^{3} / \mathrm{kg}$ ) decrease from BMA1 to BMA3. The algal and microbial mound (BMA4 and BMA5) and the lagoonal deposits with branching stromatoporoids (BMA6) have similar average low values (between $1 \times 10^{-8}$ and $1.3 \times 10^{-8} \mathrm{~m}^{3} / \mathrm{kg}$ ). The shallower lagoonal deposits (BMA7 and BMA8) and the facies formed by the erosion of the mound (BMA9) have also relatively low intermediate values (between $1.7 \times 10^{-8}$ and $1.9 \times 10^{-8} \mathrm{~m}^{3} / \mathrm{kg}$ ).
The Belgian atolls thus display a mean MS evolution opposite to that observed in both Belgian and Canadian attached platforms and instead of mean MS values increasing with the shallowest facies they appear to decrease.

\subsection{Detached carbonate platform from Canada (Canadian atoll, CA)}

Considering the detached carbonate platform from Canada, most of the MS data is negative and this main trend is interrupted by some positive peaks which do not seem to be related to a particular facies trend (Fig. 10).

A comparison of mean MS values with microfacies (Fig. 5G) shows that except for the more distal facies which has positive values (flank facies, CA1) the mean MS values are negative and don't show any relationship with facies.
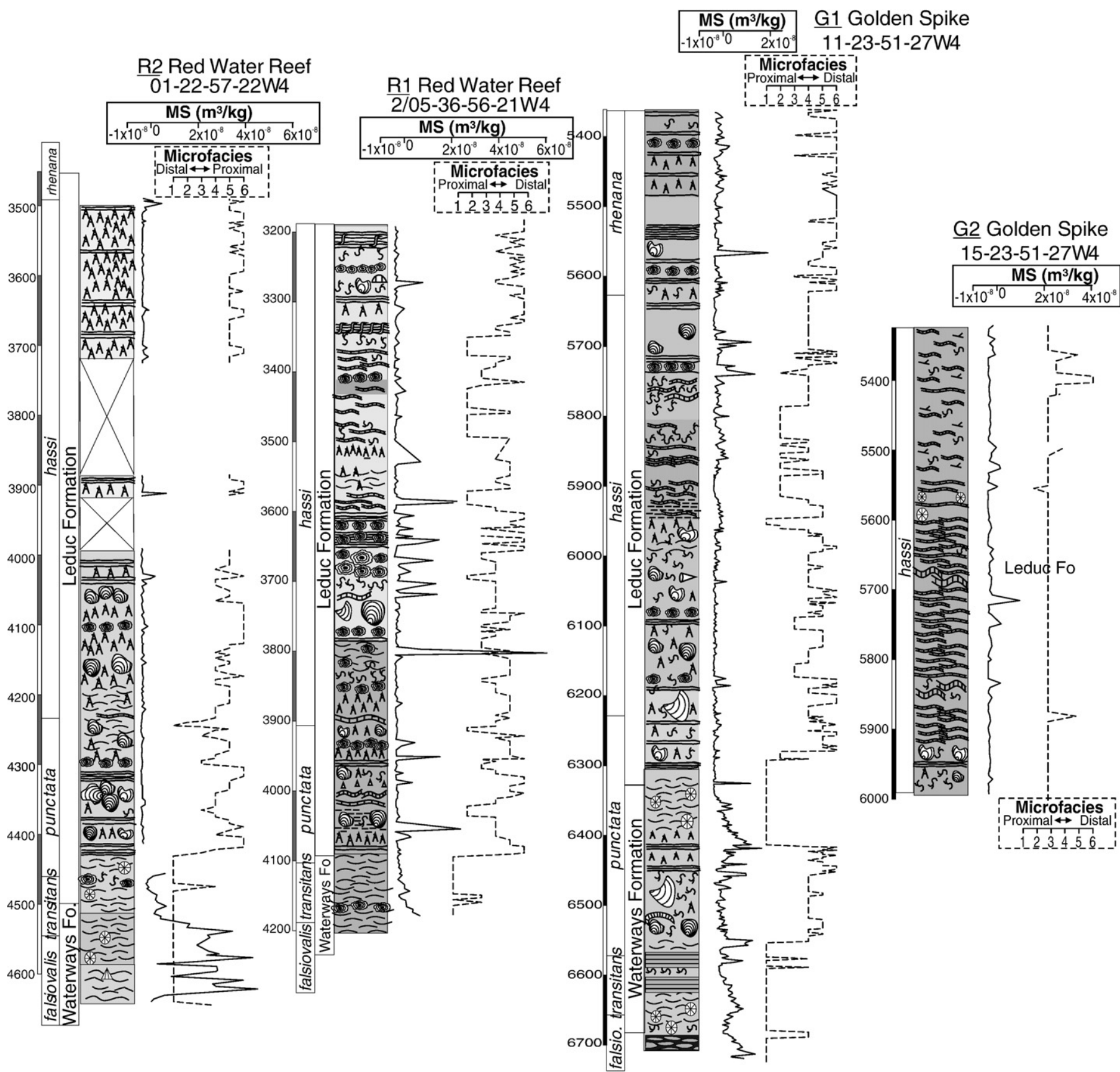

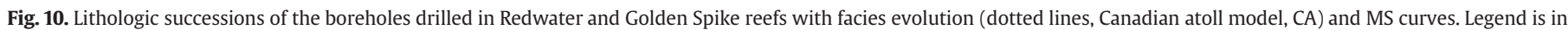
Fig. 7F. 


\section{Discussion}

\subsection{Origin of magnetic susceptibility variations}

The relationship between facies, sequences and mean magnetic susceptibility can help us to understand the origin of MS variations. In the carbonate platforms, mean MS decreases with depositional depth. For the carbonate atolls and mounds from Belgium, mean MS increases with depositional depth. For the carbonate atolls from Canada, mean MS values are negative except for the flanking basinal deposits.

Concerning the primary origin of magnetic minerals, terrigenous inputs are the main accepted origin for the MS signal (Crick et al., 2000, 2002; Ellwood et al., 2000; Stage, 2001; Racki et al., 2002; Hladil et al. 2005). However, numerous authors propose different origins for magnetic minerals like volcanism (Crick et al., 1997; Borradaile and Lagroix, 2000), black smokers (Borradaile and Lagroix, 2000), extraterrestrial impact (Ellwood et al., 2003a,b), pedogenetic minerals (Tite and Linington, 1975) and biogenic magnetite (Kirschvink and Lowenstam, 1979; Hladil et al., 2004). In our case, on a shallow-water platform and in atolls, volcanic ash, black smokers and extraterrestrial impact are considered as to have insignificant effects on the MS signal in view of oceanographic setting. Pedogenesis is common in the shallow-water platform of Belgium but as shown in Fig. 5B, pedogenetic levels (facies PF7) do not display a stronger MS signal than other lagoonal deposits. The occurrence of bacterial magnetite, in shallow-water platforms or atolls, can not be excluded during the Frasnian. However this kind of very fine-grained bacterial magnetite are mainly observed at the surface of actual sediments and their occurrence decreases strongly with depth because of a loss of the finegrained component (Blakemore, 1975; McNeill et al., 1988).

Different diagenetic processes (secondary origin) are able to modify MS after deposition, but the effects of these secondary processes on the MS of carbonate rocks are not well known. Diagenetic processes can create magnetic minerals (Henshaw and Merrill, 1980; McCabe and Elmore, 1989; Zegers et al., 2003). Processes of magnetite authigenesis can be related to the transformation of smectite into illite and remobilization of the iron for magnetite formation (Jackson et al., 1988; Katz et al., 1998) or to chemical conditions related to hydrocarbon migration and maturation of organic matter (Elmore et al., 1987; Machel and Burton, 1991). MS can also increase in relation to burial migration fluids (Schneider et al., 2004) or dolomitization (Bityukova et al., 1998; Shogenova, 1999). Diagenetic processes can also destroy magnetic minerals by the alteration of one magnetic mineral into another (oxidation of magnetite to maghemite, Henshaw and Merrill, 1980; or transformation of magnetite and pyrite into pyrite and pyrrhotite, Rochette, 1987) or by dissolution.

It is interesting to observe that the mean MS values for Canadian platform are almost ten times lower than those observed for the Belgian platform (mean Canadian values around $0.5 \times 10^{-8} \mathrm{~m}^{3} / \mathrm{kg}$ and mean Belgian values around $3.5 \times 10^{-8} \mathrm{~m}^{3} / \mathrm{kg}$ ) (Fig. 11). Concerning the

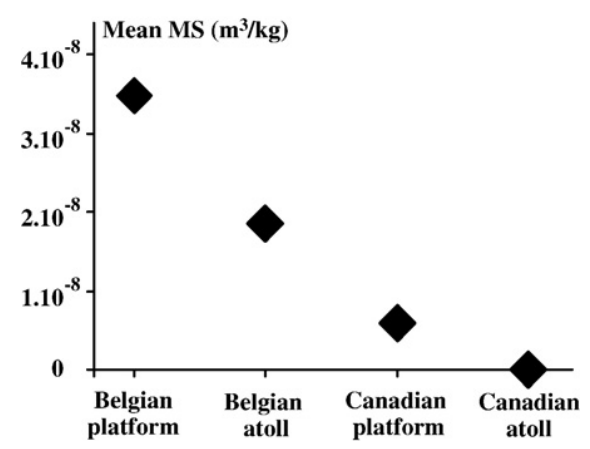

Fig. 11. Mean MS values for the carbonate Belgian platform, Canadian platform, Belgian atolls and Canadian atolls.
Belgian atolls, mean MS values are close to $2 \times 10^{-8} \mathrm{~m}^{3} / \mathrm{kg}$ and for the Canadian atolls, mean MS values are close to $0 \mathrm{~m}^{3} / \mathrm{kg}$ with a lot of negative data (Fig. 11). These lower values for the Canadian carbonates can be related to a lesser proportion of magnetic material available to the Canadian basin than the Belgian basin or to a post depositional factor that decreased magnetic susceptibility. Rochette (1987) showed that the breakdown of magnetite and its transformation into less magnetic minerals like pyrite and pyrrhotite corresponds to the anchizone-epizone boundary. In Belgium, the metamorphism does not reach this boundary (temperature $120-240{ }^{\circ} \mathrm{C}$ Fielitz and Mansy, 1999; Helsen, 1992). The Canadian attached platform reach maximal burial depth of $4000 \mathrm{~m}$ and maximal temperature of $150{ }^{\circ} \mathrm{C}$ (Shields and Brady, 1995). Burial depth of the Leduc reef was about $2500 \mathrm{~m}$ (Amthor et al., 1993), which is significantly shallower than for the outcrop belt, where the Yamnuska section is situated. Thus metamorphism and magnetite breakdown does not seem to be the reason for the lower MS in the Canadian outcrops.

A process of remagnetization by the creation of new magnetic minerals can also be considered for the Belgian Frasnian carbonates. Zegers et al. (2003) studied the magnetization of some Devonian limestones in Belgium and identified a process of magnetite formation related to the conversion of smectite to illite. This remagnetization event is especially developed in dark grey Givetian rich in clay limestones (Zegers et al., 2003). So, for the Frasnian Belgian platform and atolls, diagenetic magnetite formation cannot be excluded. However the effect of these diagenetic phase are probably minor as Frasnian limestones are not clay rich, so clay diagenesis was probably not an important process occurring in these rocks. Furthermore, clay intervals are also related to lithogenic inputs, and it seams that iron released during the smectiteillite conversion will partly remain in situ in the clay and the magnetite will crystallize in situ, in the clay aggregate (Zegers et al., 2003). So the diagenetic magnetite formation will probably enhance the primary signal which is related to lithogenic inputs.

At first sight, it appears that mean MS variations are generally consistent with environmental control (primary signal) and that secondary processes do not change strongly these trends. Actually, in the comparison of MS trends with facies trends (Figs. 7, 8, and 9), the general pattern is a relationship between MS and facies but some exceptions are observed and could be related to the influence of diagenesis. Furthermore, the influence of diagenesis by increasing or by reducing the signal can not be excluded. However a complete review of diagenetic processes affecting the magnetic minerals will be relevant to distinguish the importance of the primary and secondary processes on the MS signal.

If the MS signal is mainly related to lithogenic inputs, the opposite behaviour of MS trend along a proximal-distal transect for the platform and the atoll can be explained by differences in sedimentary rate or by higher water agitation. High carbonate production probably strongly influences mean magnetic susceptibility by diluting magnetic minerals and a low carbonate production will lead to condensed levels and concentration of magnetic minerals. In the same way, water agitation during deposition will suspend fine-grained magnetic minerals and prevent their deposition. This process can explain the magnetic susceptibility evolution in the Frasnian atoll. Actually, basinal facies surrounding the atoll are received significant inputs of clay minerals that do not accumulate on the platform tops due to higher turbulence. This explains the mean MS evolution with microfacies. During the deposition of the basinal and flank deposits (BMA1) and mud mound facies (BMA2 and 3), below storm weather wave base the accumulation rate is very low and corresponds to sediment starvation (Reitner and Neuweiller, 1995) and low water agitation during deposition. The association of these two parameters leads to magnetic minerals concentration and high mean MS values. The atoll crown facies (BMA5 and 6) correspond to high carbonate production (Einsele, 2000; Yamano et al., 2002) and high water agitation during deposition which lead to the lower mean MS values. Finally, the lagoon inside the 
atoll crown has a relatively high carbonate production rate (Yamano et al., 2002) and low water agitation and relative protection from external inputs by the surrounding atoll crown.

Concerning the mean negative magnetic susceptibility observed for the atoll facies (facies CA2 to 6), this indicates that the signal is dominated by pure limestones, with less than $0.1 \%$ of clay and $0.001 \%$ of magnetite (which are often considered as the main carriers of magnetism (Heller, 1977; Borradaile and Lagroix, 2000; Stage, 2001). It seems that the atolls were completely protected from lithogenic inputs and the carbonate production was high. Facies CA1 which corresponds to the basinal and surrounding deposits presents positive values $\left(0.6 \times 10^{-8} \mathrm{~m}^{3} / \mathrm{kg}\right)$. This can be explained by the fact that this facies was not protected and had a lower accumulation rate (it is also characterized by higher clay content). The presence of random positive MS peaks don't seem to be related to a particular facies. A possible explanation is a local increase in lithological supplies which can be related to influx of eolian material for example.

\subsection{Implications on correlations}

As magnetic susceptibility evolution differs for different platform type (Fig. 5), we have to focus now on the implication for the use of MS technique for correlations.

\subsubsection{Correlation on the same kind of depositional setting}

Within one kind of depositional setting in Belgium, MS may provide a very good tool to conduct reliable and high-resolution correlations. Based on this technique, sections in the Frasnian shallowwater carbonate platform in Belgium could be correlated to fourth- order sea-level change (da Silva and Boulvain, 2006). It also permits reasonable correlations between the Belgian mounds (Fig. 9).

Is it possible to compare magnetic susceptibility on the carbonate platform of Belgium and Alberta? In Belgium, MS increases strongly at the boundary between the biostromal and lagoonal unit and it corresponds to the lower hassi (MN zones 7-8) (Bultynck et al., 2000) or upper hassi conodont zone (MN zones 9-10) (Gouwy and Bultynck, 2000). In Alberta a similar increase of MS values is observed at the boundary between Cairn Formation and Peechee Member and this boundary can also corresponds to the lower or upper hassi conodont zone (Weissenberger, 1988; Whalen et al., 2000a). The conodont biostratigraphy does not provide enough control to allow precise correlations between the Frasnian sections from Belgium and Alberta.

Considering that the MS peaks developed in the atolls from Alberta are not related to facies trends and that their distribution seems to be random, magnetic susceptibility does not seem to offer reliable correlations between the Canadian atolls, with other sedimentary environments, or with Belgian atolls or attached platforms.

\subsubsection{Correlation from different depositional setting}

The carbonate platform sediments and the atolls of the Frasnian are time equivalent (Figs. 2B and 6B). We have seen that mean MS evolution with facies is the opposite between the carbonate platform and the time-equivalent carbonate mound. We propose a comparison of the Tailfer (da Silva and Boulvain, 2002, 2006) section from the shallow-water carbonate platform with the Lompret section (Humblet and Boulvain, 2000) from the mud mound area. In Tailfer, after the development of biostromal limestones, a strong regression caused erosion and successive development of lagoonal deposits. This

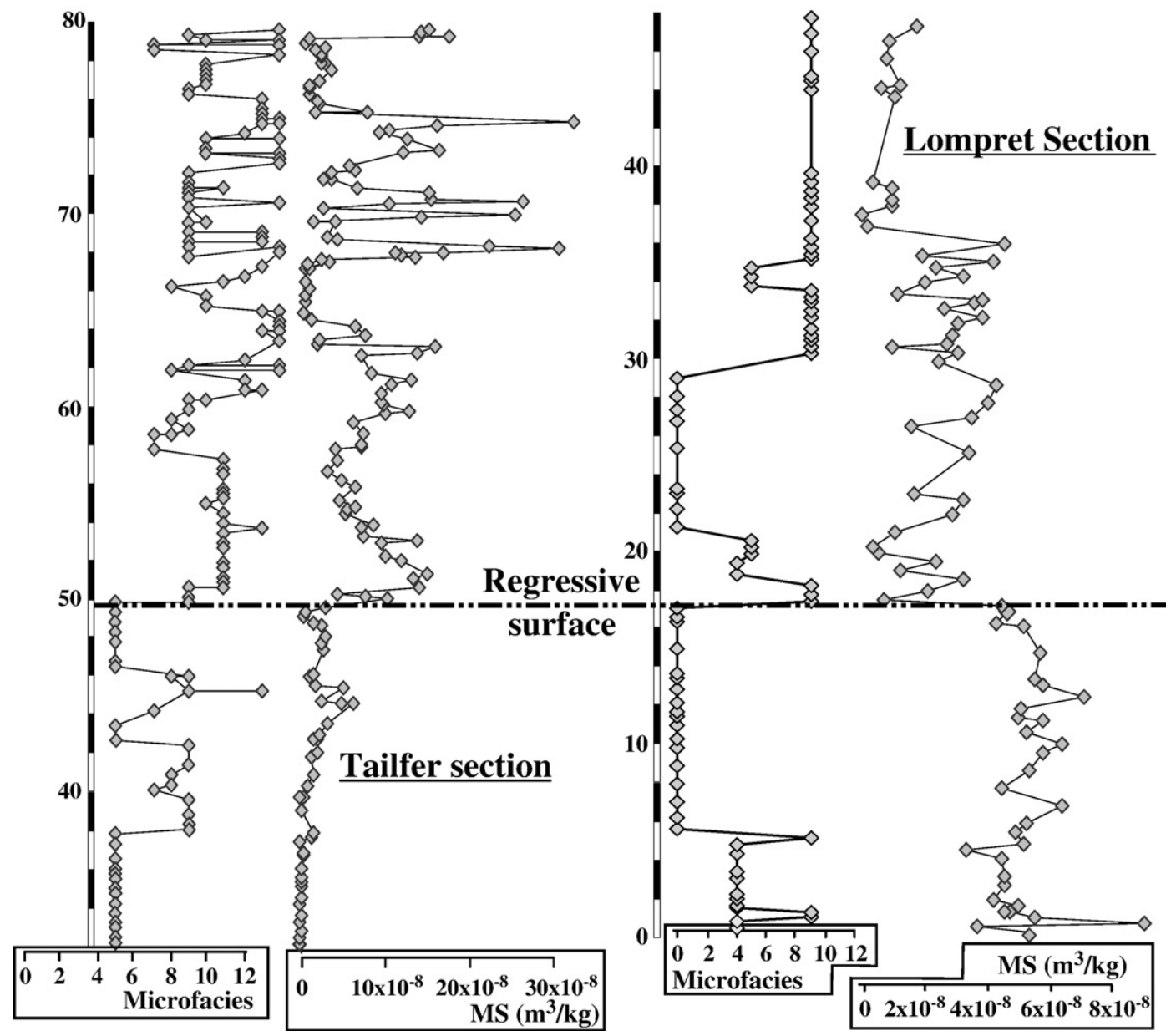

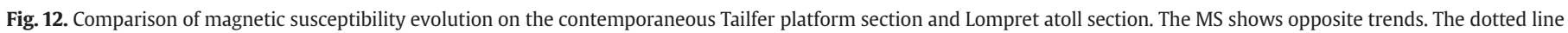
corresponds to the regressive surface described in Sections 4.1 and 4.2 and in Fig. 6. 
transition is marked by a strong increasing of magnetic susceptibility after the regression surface (from $2 \times 10^{-8} \mathrm{~m}^{3} / \mathrm{kg}$ to $6.6 \times 10^{-8} \mathrm{~m}^{3} / \mathrm{kg}$ ) (Fig. 7). In Lompret, the first unit corresponds to distal deep deposits and they are followed after the main regression by different levels of reworked material (rudstones, floatstones), corresponding to the regression and the redeposition of the eroded material (Humblet and Boulvain, 2000). This transition is marked by a decrease of magnetic susceptibility (from $5.2 \times 10^{-8} \mathrm{~m}^{3} / \mathrm{kg}$ to $2.1 \times 10^{-8} \mathrm{~m}^{3} / \mathrm{kg}$ ) (Fig. 12). So in this case, the main sea level variation is recorded in the MS signal for both environments but in an opposite way, with MS increasing at the regressive surface for the carbonate platform section (Tailfer) and decreasing at the mound section (Lompret) (Fig. 12).

\section{Conclusions}

The comparison of different carbonate platform types (attached and detached platforms) from different paleogeographic areas (Canada and Belgium) allowed us to differentiate different magnetic susceptibility behaviours.

- For the Canadian and Belgian carbonate attached platform, MS increases towards the most proximal environmental deposits, to the top of regressive sequences and with the most proximal sedimentological units. In this case, magnetic susceptibility is interpreted to be mainly related to terrigenous inputs (from fluvial or eolian inputs), that are more abundant in proximal deposits.

- For the Belgian detached platform (succession of mound and atoll stages), MS is high for the basinal and mound facies (deepest) and is low for the atoll and lagoonal deposits (shallowest) and MS decreases to the top of regressive sequences. MS distribution is, in this case, interpreted to be highly influenced by sedimentary rate and water agitation during deposition. The low sedimentary rate and water agitation during deposition of the deepest facies allowed the concentration of the magnetic minerals in the basinal and mound facies.

- For the Canadian detached platform, the atoll and lagoonal facies present low, mainly negative MS values. The basinal and flank facies are characterized by higher slightly positive values. They are no strong relationship between sequences, facies and MS. These trends are interpreted to be related to high carbonate productivity, high water agitation during deposition or large distance from siliciclastic sources.

As already proposed by different authors, the results presented here are pointing to a MS signal probably dominated by lithogenic inputs (Crick et al., 2000; Ellwood et al., 2000; Hladil, 2002). The proportion of lithogenic inputs seems to be higher during low sea level, when important portion of continental area are emerged. The influences of varying clastic supplies, varying carbonate accumulation rates and of potential diagenesis are probably key factors influencing the MS signal variations in carbonate sediments.

These different behaviours of MS with sedimentary environments related to the influence of sedimentary rate and water agitation during deposition and of potential diagenesis, imply difficulties for MS correlations and suggest that the use of MS as a correlation tool must be carried out with caution. Correlations of sections from the same type of platform will probably be better than correlations between different types of platforms such as between atolls and attached platforms.

\section{Acknowledgments}

This study forms part of a PhD finished in 2004 (A-C. da Silva) and a $\mathrm{PhD}$ in progress (C. Mabille), and both were carried out with the financial support of a FRIA grant. Anne-Christine da Silva acknowledges the F.N.R.S. (Belgium) for a position of Postdoctoral Researcher. Thanks to Olivier Averbuch, from Lille University for allowing the access to KLY2 device for magnetic susceptibility measurements. A-C da Silva received also financial support for field trip in Alberta (Bourse de la Comunauté Française de Belgique and Bourse de l'Académie des Sciences de Belgique, Fondation A. de Potter) and for core access (Encana). Special thanks also to Benoit Beauchamp for his help and logistic support and to Tijmen Hartel for support on the field. Many thanks to the journal reviewers (Steve Kershaw and Jindrich Hladil) for their very interesting comments and discussions which greatly improve the paper. Thanks also to the editors of this special issue Yasufumi Iryu and Brian Jones.

\section{References}

Amthor, J.E., Mountjoy, E.W., Machel, H.G., 1993. Subsurface dolomites in the Upper Devonian Leduc Formation buildups: central part of Rimbey-Meadowbrook reef trend, Alberta, Canada. Bull. Can. Petrol. Geol. 41, 164-185.

Bityukova, L., Shogenova, A., Goetze, H.J., 1998. Influence of chemical composition on petrophysical properties of early Paleozoic carbonate rocks in Estonia. In: Goetze, H.J., Schmidt, S. (Eds.), Modelling Techniques in Geology and Geophysics by the Aid of Geoscientific Information Systems (GIS). Phys. Chem. Earth, vol. 23, pp. 309-316.

Blakemore, R., 1975. Magnetotactic bacteria. Science 190, 377-379.

Borradaile, G.J., Lagroix, F., 2000. Magnetic characterization using a three-dimensional hysteresis projection, illustrated with a study of limestones. Geophys. J. Int. 141, 213-226.

Boulvain, F., 2001. Facies architecture and diagenesis of Belgian Late Frasnian carbonate mounds. Sed. Geol. 145, 269-294.

Boulvain, F., 2007. Frasnian carbonate mounds from Belgium: sedimentology and palaeoceanography. In: Alvaro, J.J., Aretz, M., Boulvain, F., Munnecke, A., Vachard, D., Vennin, E. (Eds.), Palaeozoic Reefs and Bioaccumulations: Climatic and Evolutionary Controls. Geol. Soc., London, Sp. Publ., 275, pp. 125-142.

Boulvain, F., Bultynck, P., Coen, M., Coen-Aubert, M., Helsen, S., Lacroix, D., Laloux, M. Casier, J.G., Dejonghe, L., Dumoulin, V., Ghysel, P., Godefroid, J., Mouravieff, N., Sartenaer, P., Tourneur, F., Vanguestaine, M., 1999. Les formations du Frasnien de la Belgique. Mem. Geol. Survey Belgium 44, 125.

Boulvain, F., Cornet, P., da Silva, A.C., Delaite, G., Demany, B., Humblet, M., Renard, M., Coen-Aubert, M., 2004. Reconstructing atoll-like mounds from the Frasnian of Belgium. Facies 50, 313-326.

Bultynck, P., Coen-Aubert, M., Godefroid, J., 2000. Summary of the state of correlation in the Devonian of the Ardennes (Belgium-NE France) resulting from the decisions of the SDS. Courier Forschungsinstitut Senckenberg 225, 91-114.

Copper, P., 2002. Silurian and Devonian reefs: 80 million years of global greenhouse between two ice ages. In: Kiessling, W., Flügel, E., Golonka, J. (Eds.), Phanerozoic Reef Patterns SEPM, Special Publication, 72, pp. 181-238.

Crick, R.E., Ellwood, B.B., El Hassani, A., Feist, R., Hladil, J., 1997. Magnetosusceptibility event and cyclostratigraphy (MSEC) of the Eifelian-Givetian GSSP and associated boundary sequences in north Africa and Europe. Episodes 20,167-175.

Crick, R.E., Ellwood, B.B., El Hassani, A., Feist, R., 2000. Proposed magnetostratigraphy susceptibility magnetostratotype for the Eifelian-Givetian GSSP (Anti-Atlas, Morocco). Episodes 23, 93-101.

Crick, R.E., Ellwood, B.B., Hladil, J., El Hassani, A., Hrouda, F., Chlupac, I., 2001 Magnetostratigraphy susceptibility of the Pridolian-Lochkovian (Silurian-Devonian) GSSP (Klonk, Czech Republic) and coeval sequence in Anti-Atlas Morocco. Palaeogeogr., Palaeoclimatol., Palaeoecol. 167, 73-100.

Crick, R.E., Ellwood, B.B., Feist, R., El Hassani, A., Schindler, E., Dreesen, R., Over, D.J. Girard, C., 2002. Magnetostratigraphy susceptibility of the Frasnian/Famennian boundary. Palaeogeogr., Palaeoclimatol., Palaeoecol. 181, 67-90.

da Silva, A.C., Boulvain, F., 2002. Sedimentology, magnetic susceptibility and isotopes of a Middle Frasnian carbonate platform: Tailfer section, Belgium. Facies 46, 89-102.

da Silva, A.C., Boulvain, F., 2003. Sedimentology, magnetic susceptibility and correlations of Middle Frasnian platform limestone (Tailfer and Aywaille sections, Belgium). Geologica Belgica 6, 81-96.

da Silva, A.C., Boulvain, F., 2004. From paleosols to carbonate mounds: facies and environments of Middle Frasnian carbonate platform in Belgium. Geol. Q. 48, 253-266.

da Silva, A.C., Boulvain, F., 2006. Upper Devonian carbonate platform correlations and sea level variations recorded in magnetic susceptibility. Palaeogeogr., Palaeoclimatol., Palaeoecol., 240, 373-388.

Davies, T.A., Hay, W.W., Southam, J.R., Worsley, T.R., 1977. Estimates of Cenozoic oceanic sedimentation rates. Science 197, 53-55.

Devleeschouwer, X., 1999. La transition Frasnien-Famennien (Dévonien Supérieur) en Europe: Sédimentologie, stratigraphie séquentielle et susceptibilité magnétique, Thèse inédite de Doctorat en Sciences présenté à l'Université Libre de Bruxelles, Bruxelles, $411 \mathrm{pp}$.

Einsele, G., 2000. Sedimentary basins : evolution, facies, and sediment budget. Springer. $792 \mathrm{pp}$.

Ellwood, B.B., Crick, R.E., El Hassani, A., 1999. Magnetosusceptibility event and cyclostratigraphy (MSEC) method used in geological correlation of Devonian rocks from Anti-Atlas Morocco. AAPG Bull. 83, 1119-1134.

Ellwood, B.B., Crick, R.E., El Hassani, A., Benoist, S.L., Young, R.H., 2000. Magnetosusceptibility event and cyclostratigraphy method applied to marine rocks: detrital input versus carbonate productivity. Geology 28, 1135-1138.

Ellwood, B.B., Crick, R.E., Carcia-Alcade Fernandez, J.L., Soto, F.M., Truyóls-Massoni, M. El Hassani, A., Kovas, E.J., 2001. Global correlation using magnetic susceptibility data from Lower Devonian rocks. Geology 29, 583-586.

Ellwood, B.B., Benoist, S.L., El Hassani, A., Wheeler, C., Crick, R.E., 2003a. Impact ejecta layer from the Mid-Devonian: possible connection to global mass extinctions. Science 300, 1734-1737. 
Ellwood, B.B., MacDonald, W.D., Wheeler, C., Benoist, S.L., 2003b. The K-T boundary in Oman: identified using magnetic susceptibility field measurements with geochemical confirmation. Earth Planet. Sc. Lett. 206, 529-540.

Ellwood, B.B., Garcia-Alcalde, J.L., El Hassani, A., Hladil, J., Soto, F.M., Truyols-Massoni, M. Weddige, K., Koptikova, L., 2006. Stratigraphy of the Middle Devonian boundary: formal definition of the susceptibility magnetostratotype in Germany with comparisons to sections in the Czech Republic, Morocco and Spain. Tectonophysics $418,31-49$.

Ellwood, B.B., Carlton, E.B., MacDonald, W.D., 2007. Magnetostratigraphy susceptibility of the Upper Ordovician Kope Formation, northern Kentucky. Palaeogeogr. Palaeoclimatol., Palaeoecol. 243, 42-54.

Elmore, R.D., Engel, M.H., Crawford, L., Nick, K., Imbus, S., Sofer, Z., 1987. Evidence for relationship between hydrocarbons and authigenic magnetite. Nature 325, 428-430.

Fielitz, W., Mansy, J.L., 1999. Pre- and synorogenic burial metamorphism in the Ardenne and neighbouring areas (Rhenohercynian zone, central European Variscides). Tectonophysics 309, 227-256.

Gouwy, S., Bultynck, P., 2000. Graphic correlation of Frasnian sections (Upper Devonian) in the Ardennes, Belgium. Bull. IRSNB 70, 25-52.

Handford, C.R., Loucks, R.G., 1993. Carbonate depositional sequences and systems tract responses of carbonate platforms to relative sea-level changes. In: Loucks, R.G., Sarg J.F. (Eds.), Carbonate Sequence Stratigraphy. Recent Developments and Applications. AAPG Mem., 57, pp. 3-41.

Heckel, P.H., Witzke, B.J., 1979. Devonian world paleogeography determined from distribution of carbonates and related lithic paleoclimatic indicators. In: House, M.R. Scrutton, C.T., Bassett, M.G. (Eds.), The Devonian System. Spec. Pap. Paleontol., vol. 23, pp. 99-123.

Heller, F., 1977. Paleomagnetism of Upper Jurassic limestones from Southern Germany J. Geophys. 42, 475-488.

Helsen, S., 1992. Conodont colour alteration maps for Paleozoic strata in Belgium, Northern France and Westernmost Germany - preliminary results. Ann. Soc. Géol. Belgique 115, 135-143.

Henshaw, P.C., Merrill, R.T., 1980. Magnetic and chemical changes in marine sediments. Rev. Geophys. Space Phys. 18, 483-504.

Hladil, J., 2002. Geophysical records of dispersed weathering products on the Frasnian carbonate platform and early Famennian ramps in Moravia, Czech Republic: proxies for eustasy and palaeoclimate. Palaeogeogr., Palaeoclimatol., Palaeoecol. 181, 213-250.

Hladil, J., Bosak, P., Slavik, L., Carew, J.L., Mylroie, J.E., Gersl, M., 2003a. Early diagenetic origin and persistence of gamma-ray and magnetosusceptibility patterns in latform carbonates: comparison of Devonian and Quaternary sections. Phys. Chem. Earth 28, 719-727.

Hladil, J., Bosak, P., Slavik, L., Carew, J.L., Mylroie, J.E., Gersl, M., 2003b. A pragmatic test of the early origin and fixation of gamma-ray spectrometric (U, Th) and magnetosusceptibility $(\mathrm{Fe})$ patterns related to sedimentary cycle boundaries in pure platform limestones. Carbonates evaporites 18, 89-107.

Hladil, J., Carew, J.L., Mylroie, J.E., Pruner, P., Kohout, T., Jell, J.S., Lacka, B., Langrova, A 2004. Anomalous magnetic susceptibility values and traces of subsurface microbial activity in carbonate banks on San Salvador Island, Bahamas. Facies 50, 161-182.

Hladil, J., Gersl, M., Strnad, L., Frana, J., Langrova, A., Spisiak, J., 2005. Stratigraphic variation of complex impurities in platform limestones and possible significance of atmospheric dust : a study with emphasis on gamma-ray spectrometry and magnetic susceptibility outcrop logging (Eifelian-Frasnian, Moravia, Czech Republic). Intern. J. Earth Sc. 95, 703-723.

Humblet, M., Boulvain, F., 2000. Sedimentology of the Bieumont Member: influence of the Lion Member carbonate mounds (Frasnian, Belgium) on their sedimentary environment. Geologica Belgica 3, 97-118.

Jackson, M., McCabe, C., Ballard, M.M., Van Der Voo, R., 1988. Magnetite authigenesis and diagenetic paleotemperatures across the northern Appalachian basin. Geology $16,592-595$.

Joachimski, M., Van Geldern, R., Breisig, S., Buggisch, W., Day, J., 2004. Oxygen isotope evolution of biogenic calcite and apatite during the Middle and Late Devonian. Intern. J. Earth Sc. 93, 542-553.

Johnson, J.G., Klapper, G., Sandberg, C.A., 1985. Devonian eustatic fluctuations in Euramerica. Geol. Soc. Am. Bull. 96, 567-587.

Katz, B., Elmore, R.D., Cogoini, M., Ferry, S., 1998. Widespread chemical remagnetization: orogenic fluids or burial diagenesis of clays? Geology 26, 603-606.

Kiessling, W., Flügel, E., Golonka, J., König, D., Röper, W., Steuding, R., Haas, A. and Dässler, R., 2003. The Paleoreefs projects, http://193.175.236.205/paleo/.

Kirschvink, J.L., Lowenstam, H.A., 1979. Mineralization and magnetization of chiton teeth: paleomagnetic, sedimentologic, and biologic implications of organic magnetite. Earth Planet. Sc. Lett. 44, 193-204.

Klapper, G., 1988. The Montagne Noire Frasnian (Upper Devonian) conodont succession. In: Mc Millan, N.J., Embry, A.F., Glass, D.J. (Eds.), Devonian of the World. Proceeding of the Second International Symposium on the Devonian System. Calgary, Canada. Can. Soc. Petrol. Geol. Mem., vol. 14, pp. 449-468.

Mabille, C., Boulvain, F., 2007. Sedimentology and magnetic susceptibility of the Upper Eifelian-Lower Givetian (Middle Devonian) in SW Belgium: insights into carbonate platform initiation. In: Alvaro, J.J., Aretz, M., Boulvain, F., Munnecke, A., Vachard, D. Vennin, E. (Eds.), Palaeozoic Reefs and Bioaccumulations. Climatic and Evolutionary Controls. Geol. Soc. Sp. Publ., vol. 275, pp. 109-123.

Machel, H.G., Burton, E.A., 1991. Causes of spatial distribution of anomalous magnetization in hydrocarbon seepage environments. AAPG Bull. 75, 1864-1876.

Mallamo, M.P., Geldsetzer, H.H.J., 1991. The western margin of the Upper Devonian Fairholme Reef Complex, Banff-Kananaskis area, southwestern Alberta. Current Research, Part B, Geol. Surv. Canada Paper 91, 59-69.
McCabe, C., Elmore, R.D., 1989. The occurence and origin of late Paleozoic remagnetizations in the sedimentary rocks of North America. Rev. Geophys. 27, 471-494.

McGillivray, J.G., Mountjoy, E.W., 1975. Facies and related reservoir characteristics Golden Spike reef complex, Alberta. Bull. Can. Petrol. Geol. 23, 753-809.

McKerrow, W.S., Scotese, C.R., 1990. Paleozoic palaeogeography and biogeography. Geol. Soc. London Mem. 12, 433 pp.

McNeill, D.F., Ginsburg, R.N., Chang, S.B.R., Kirschvink, J.L., 1988. Magnetostratigraphic dating of shallow-water carbonates from San Salvador, Bahamas. Geology 16, 8-12.

Meijers Drees, N.C., Geldsetzer, H.H.J., 1984. Correlations between upper Devonian surface and subsurface map units in West-Central Alberta. Current Research, Part B, Geol. Surv. Canada 84, 337-349.

Oldale, H.S., Munday, R.J., Ma, K., Meijers Drees, N.C., 1996. Devonian Beaverhill Lake group of the Western Canada sedimentary basin. In: Mossop, G.D., Shetsen, I. (Eds.), Geological Atlas of the Western Canada Sedimentary Basin. Alberta Geological Survey. http://www.ags.gov.ab.ca/publications/.

Potma, K., Weissenberger, J.A.W., Wong, P.K., Gilhooly, M.G., 2001. Toward a sequence stratigraphic framework for the Frasnian of the Western Canada basin. Bull. Can. Petrol. Geol. 49, 37-85.

Racki, G., Racka, M., Matyja, H., Devleeschouwer, X., 2002. The Frasnian / Famennian boundary interval in the South Polish-Moravian shelf basins: integrated eventstratigraphical approach. Palaeogeogr., Palaeoclimatol., Palaeoecol. 181, 251-297.

Reitner, J., Neuweiller, F., 1995. Supposed principal controlling factors of rigid micrite build-ups. In: Reitner, J., Neuweiller, F. (Eds.), Mud mounds: A Polygenic Spectrum of Fine-grained Carbonate Buildup. Facies, 32, pp. 62-64.

Rochette, P., 1987. Metamorphic control of the magnetic mineralogy of black shales in the Swiss Alps: toward the use of "magnetic isogrades". Earth Planet. Sc. Lett. 84, 446-456.

Sandberg, C.A., Ziegler, A.M., Dreesen, R., Butler, J.L., 1992. Conodont biochronology, biofacies, taxonomy and event stratigraphy around Middle Frasnian Lion mudmound (F2h), Frasnes, Belgium. Courier Forschungsinstitut Senckenberg $150,1-87$.

Schneider, J., de Wall, H., Kontny, A., Bechstädt, T., 2004. Magnetic susceptibility variations in carbonates of the La Vid Group (Cantabrian Zone, NW-Spain) related to burial diagenesis. Sed. Geol. 166, 73-88.

Shields, M.J., Brady, P.V., 1995. Mass balance and fluid flow constraints on regional-scale dolomitization, Late Devonian, Western Canada sedimentary basin. Bull. Can. Petrol. Geol. 43, 371-392.

Shogenova, A., 1999. The influence of dolomitization on the magnetic properties of Lower Palaeozoic carbonate rocks in Estonia. In: Tarling, D.H., Turner, P. (Eds.), Palaeomagnetism and Diagenesis in Sediments. Geol. Soc. London, Sp. Publ., London, vol. 151, pp. 167-180

Stage, M., 2001. Magnetic susceptibility as carrier of a climatic signal in chalk. Earth Planet. Sc. Lett. 188, 17-27.

Streel, M., Caputo, M.V., Loboziak, S., Melo, J.H.G., 2000. Late Frasnian-Famennian climates based on palynomorph analyses and the question of the Late Devonian glaciations. Earth-Sc. Rev. 52, 121-173.

Switzer, S.B., Holland, W.G., Christie, D.S., Graf, G.C., Hedinger, A.S., McAuley, R.J., Wiersbicki, R.A., Packard, J.J., 1994. Devonian Woodbend-Winterburn strata of the Western Canada sedimentary basin. In: Mossop, G.D., Shetsen, I. (Eds.), Geological Atlas of the Western Canada Sedimentary Basin. Can. Soc. Petrol. Geol., Core Conference, pp. 132-147.

Tite, M.S., Linington, R.E., 1975. Effect of climate on the magnetic susceptibility of soils. Nature 256, 565-566.

Torsvik, T.H., Cocks, L.R.M., 2004. Earth geography from 400 to 250 Ma: a palaeomagnetic, faunal and facies review. J. Geol. Soc. London 161, 555-572.

Vail, P.R., Mitchum Jr., R.M., Thompson, S., 1977. Seismic stratigraphy and global changes of sea level, Part 4: Global cycles of relative changes of sea level. In: Payton, C.E. (Ed.), Seismic Stratigraphy - Applications to Hydrocarbon Exploration. AAPG Mem., 26, pp. 83-97.

van Buchem, F.S.P., Eberli, G.P., Whalen, M.T., Mountjoy, E.W., Homewood, P.W., 1996. The basinal geochemical signature and platform margin geometries in the Upper Devonian mixed carbonate-siliciclastic system of western Canada. Bull. Geol. Soc. France 167, 685-699.

Walden, J., Oldfield, F., Smith, J., 1999. Environmental magnetism: a practical guide. Technical Guide No. 6. Quaternary Research Association, London. 243 pp.

Weissenberger, J.A.W., 1988. Sedimentology and preliminary conodont biostratigraphy of the Upper Devonian Fairholme group, Nordegg area, West-central Alberta, Canada. In: Mc Millan, N.J., Embry, A.F., Glass, D.J. (Eds.), Devonian of the World. Proceeding of the Second International Symposium on the Devonian System. Calgary, Canada. Can. Soc. Petrol. Geol. Mem., vol. 14, pp. 451-461.

Weissenberger, J.A.W., 1994. Frasnian reef and basinal strata of West Central Alberta: a combined sedimentological and biostratigraphic analysis. Bull. Can. Petrol. Geol. 42, $1-25$.

Wendte, J.C., 1992. Cyclicity of Devonian strata in the western Canada sedimentary basin. In: Wendte, J.C., Stoakes, F.A., Campbell, C.V. (Eds.), Devonian-Early Mississippian Carbonates of the Western Canada Sedimentary Basin: A Sequence Stratigraphic Framework. Soc. Econ. Paleontol. Mineral., 28, pp. 25-39. Short Course.

Whalen, M.T., Day, J., 2005. Magnetic susceptibility, biostratigraphy, and sequence stratigraphy: insights into Devonian Carbonate platform development and basin infilling, western Alberta. AAPG Annual Convention Abstracts 14, A151.

Whalen, M.T., Eberli, G.P., van Buchem, F.S.P., Mountjoy, E.W., 2000a. Facies models and architecture of Upper Devonian carbonate platforms (Miette an Ancient wall) Alberta, Canada. In: Homewood, P.W., Eberli, G.P. (Eds.), Genetic Stratigraphy on the Exploration and the Production Scales. Case studies from the Pennsylvanian of the Paradox Basin and the Upper Devonian of Alberta. Bull. Centres Rech. Explor.-Prod. Elf-Aquitaine Mém., vol. 24, pp. 139-178. 
Whalen, M.T., Eberli, G.P., van Buchem, F.S.P., Mountjoy, E.W., Homewood, P.W., 2000b. Bypass margins, basin-restricted wedges and platform-to-basin correlation, Upper Devonian, Canadian Rocky Mountains: implications for sequence stratigraphy of carbonate platform systems. J. Sed. Res. 70, 913-936.

Worsley, T.R., Davies, T.A., 1979. Sea-level fluctuation and deep-sea sedimentation rates. Science 203, 455-456.
Yamano, H., Kayanne, H., Matsuda, F., Tsuji, Y., 2002. Lagoonal facies, ages, and sedimentation in three atolls in the Pacific. Marine Geol. 185, 233-247.

Zegers, T.E., Dekkers, M.J., Baily, S., 2003. Late Carboniferous to Permian remagnetization of Devonian limestones in the Ardennes: Role of temperature, fluids, and deformation. J. Geophys. Res. 108, 5/1-5/19. 